\title{
Sapindaceae em um remanescente de Floresta Estacional Semidecidual no município de Engenheiro Paulo de Frontin, RJ, Brasil
}

\author{
Annelise Frazão ${ }^{1,2,3,4}$ e Genise Vieira Somner ${ }^{2}$
}

Recebido: 23.02.2016; aceito: 22.07.2016

\begin{abstract}
Sapindaceae in a remnant of Semideciduous Forest in the Municipality of Engenheiro Paulo de Frontin, Rio de Janeiro State, Brazil). This paper presents a floristic study of the Sapindaceae in a remnant of Semideciduous Forest in the Municipality of Engenheiro Paulo de Frontin, Rio de Janeiro State, Brazil. 20 species in seven genera were identified: three shrubs or trees belonging to Allophylus (three species); six trees belonging to Cupania (four species), Matayba (one), and Sapindus (one); and 11 lianas belonging to Paullinia (four species), Serjania (six), and Urvillea (one). Among these species, Allophylus exappendiculatus Somner, Frazão \& Ferrucci, is a recently described species discovered during this study; Paullinia thalictrifolia Radlk. and Serjania gracilis Radlk. had not been collected for more than 40 years in the State of Rio de Janeiro State. This study contributed to the knowledge of the Sapindaceae from a Semideciduous Forest of Southeastern Brazil and added a new species to the national flora.
\end{abstract}

Keywords: Atlantic Forest, Flora, Sapindales, Southeastern Brazil

RESUMO - (Sapindaceae em um remanescente de Floresta Estacional Semidecidual no município de Engenheiro Paulo de Frontin, RJ, Brasil). Este trabalho apresenta um estudo florístico de Sapindaceae em um remanescente de Floresta Estacional Semidecidual no município de Engenheiro Paulo de Frontin, Estado do Rio de Janeiro, Brasil. Foram registradas 20 espécies, distribuídas em sete gêneros, sendo três arbustivo-arbóreas do gênero Allophylus; seis arbóreas dos gêneros Cupania (quatro), Matayba (uma) e Sapindus (uma); e 11 lianas dos gêneros Paullinia (quatro), Serjania (seis) e Urvillea (uma). Dentre essas espécies, destacamos Allophylus exappendiculatus Somner, Frazão \& Ferrucci, uma espécie recentemente descrita, descoberta ao longo deste estudo, e Paullinia thalictrifolia Radlk. e Serjania gracilis Radlk., não coletadas há mais de 40 anos no Estado do Rio de Janeiro. Este trabalho contribuiu para melhorar nosso conhecimento das Sapindaceae de uma Floresta Estacional Semidecidual do sudeste brasileiro e adicionou uma nova espécie à flora nacional.

Palavras-chave: Flora, Mata Atlântica, Sapindales, Sudeste do Brasil

\section{Introdução}

Sapindaceae é uma família monofilética (Gadek et al. 1996, Harrington et al. 2005, Buerki et al. 2010) e predominantemente distribuída nas regiões tropical e subtropical (Buerki et al. 2010, AcevedoRodríguez et al. 2011). No Brasil, ocorrem 28 gêneros e 418 espécies (Somner et al. 2015). A família está bem representada no domínio fitogeográfico da Mata Atlântica, principalmente nas Florestas Ombrófilas Densas, Florestas Estacionais Semideciduais, Florestas Ombrófilas de Terras Baixas e nas Restingas
(Somner et al. 2015). Nessas formações, apresenta indivíduos de hábitos variados, incluindo árvores, arbustos, lianas e, menos frequentemente, trepadeiras herbáceas (Acevedo-Rodríguez 2011, Somner et al. 2015).

AMataAtlântica é um dos domínios fitogeográficos mais ricos em diversidade biológica do planeta, sendo considerado um dos hotspots de biodiversidade mais ameaçados (Myers et al. 2000). Neste domínio fitogeográfico, a Floresta Estacional Semidecidual é uma das fitofisionomias com maior risco de supressão vegetacional em decorrência da expansão das

1. Parte do Trabalho de Conclusão de Curso da primeira Autora

2. Universidade Federal Rural do Rio de Janeiro, Instituto de Biologia, Departamento de Botânica, Caixa Postal 74582, BR 465, km 47, 23851-970 Seropédica, RJ, Brasil

3. Universidade de São Paulo, Instituto de Biociências, Departamento de Botânica, Rua do Matão, 277, Edifício Aylthon B. Joly (Sobre as Ondas), Butantã, 05508-090 São Paulo, SP, Brasil

4. Autor de correspondência: annelisefrazao@gmail.com 
fronteiras agrícolas e urbanas no sudeste brasileiro nos últimos anos (Lima 2001). Esta fitofisionomia, a qual é constituída por cerca de $20 \%$ das mais de 16 mil espécies registradas para a Mata Atlântica (Flora do Brasil 2020, em construção), é uma formação transicional localizada entre as florestas de encosta litorâneas e as formações não florestais distribuídas no interior do continente (Veloso et al. 1991). Do total da diversidade de angiospermas catalogadas para Florestas Estacionais Semideciduais (ca. de 2.900 espécies), a família Sapindaceae está representada por 91 espécies (Somner et al. 2015).

No Estado do Rio de Janeiro, estudos voltados para a investigação da diversidade vegetal envolvendo Sapindaceae são registrados para Floresta Ombrófila Densa na região de Paraty (Somner 1997), em Nova Friburgo (Lima et al. 1997), em Niterói e Maricá (Barros 2008), para Floresta Ombrófila Densa de Terras Baixas em Silva Jardim (Lima et al. 2008), e para algumas restingas (Faria 2009, Somner 2001, Somner et al. 2009a). No entanto, estudos dedicados a Sapindaceae em Florestas Estacionais Semideciduais do Estado são inexistentes, verificando-se apenas trabalhos fitossociológicos que listaram espécies deste grupo ao passo que caracterizaram a estrutura da floresta das áreas estudadas (Silva et al. 2001, Kurtz et al. 2009, Dan et al. 2010). Dessa forma, evidencia-se a relevância de estudos com a família no Estado do Rio de Janeiro, principalmente no tipo de formação supracitada.

Aárea de estudo, a qual apresenta poucos trabalhos publicados voltados para o estudo de catalogação da sua biodiversidade (e.g., Luz et al. 2007), faz parte da região Centro-Sul Fluminense e está situada em meio a fragmentos florestais interconectados, os quais compõem um dos corredores da biodiversidade da Mata Atlântica (Fundação SOS Mata Atlântica 2010). Apesar de guardar áreas florestais conservadas, a região Centro-Sul Fluminense no Estado do Rio de Janeiro apresenta franca expansão urbana nos últimos anos (Bastos \& Napoleão 2010), o que demonstra a relevância de trabalhos como o apresentado aqui.

Este trabalho, desenvolvido em um remanescente de Floresta Estacional Semidecidual do Estado do Rio de Janeiro, apresenta os resultados do primeiro estudo florístico focado em Sapindaceae realizado neste tipo de fitofisionomia no Estado do Rio de Janeiro. São apresentadas aqui descrições morfológicas detalhadas, comentários taxonômicos, dados fenológicos e informações de distribuição geográfica, além de uma chave para identificação das espécies registradas.

\section{Material e métodos}

O Instituto Zoobotânico de Morro Azul - IZMA (22²9'41,1"S; 43³4'03,5"W) é um fragmento de Floresta Estacional Semidecidual de aproximadamente 15 ha situado em Morro Azul do Tinguá, Município de Engenheiro Paulo de Frontin, RJ, Brasil (figura 1). Encontra-se acima de 600 $m$ de altitude, no planalto montanhoso do Estado do Rio de Janeiro, região do Centro Sul Fluminense, e incluído no Corredor de Biodiversidade da Serra do Mar (Fundação SOS Mata Atlântica 2010). Segundo a classificação de Köppen (1948), o clima da região enquadra-se no tipo Cwa, temperado brando, com inverno seco e verão quente. A temperatura média anual é de $22^{\circ} \mathrm{C}$ e a pluviosidade média anual é de $1.480 \mathrm{~mm}$, com chuvas concentradas de dezembro a março e com uma estação relativamente seca de julho a setembro (Ribeiro 1998).

O levantamento das espécies de Sapindaceae do IZMA foi realizado entre dezembro/2008 e novembro/2010. Os espécimes foram coletados através de caminhadas livres ao longo de trilhas pré-existentes ou criadas na área de estudo. O material botânico foi herborizado conforme métodos convencionais (Mori et al. 1985) e, posteriormente, incorporado à coleção do Herbário RBR.

Os espécimes foram identificados com o auxílio de bibliografia especializada (Radlkofer 1931-1934,

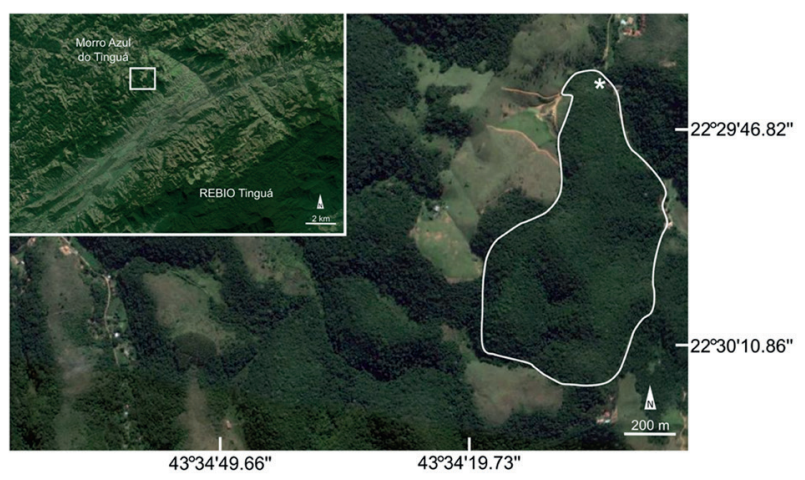

Figura 1. Mapa de localização do Instituto Zoobotânico de Morro Azul (IZMA), Engenheiro Paulo de Frontin, RJ, Brasil. A área de estudo está ilustrada com imagens de satélite que mostram o Instituto Zoobotânico de Morro Azul (mapa ampliado; IZMA) e fragmentos adjacentes. É possível observar graus variados de conectividade entre fragmentos e a proximidade geográfica do IZMA em relação à Reserva Biológica do Tinguá (REBIO Tinguá). O asterisco indica a localização da sede do IZMA.

Figure 1. Location map of the Instituto Zoobotânico de Morro Azul (IZMA), Engenheiro Paulo de Frontin, Rio de Janeiro State, Brazil. The study area is illustrated with satellite images that show the Instituto Zoobotânico de Morro Azul (blown up map; IZMA) and adjacent fragments. It is possible to observe variable degrees of connectivity among fragments and geographic proximity of the IZMA in relation to Reserva Biológica do Tinguá (REBIO Tinguá). The asterisk indicates the main base of the IZMA. 
Somner et al. 2009b) e também por comparação com material do acervo dos herbários consultados. Os nomes das espécies e autores foram checados na Lista de Espécies da Flora do Brasil (Somner et al. 2015), IPNI (The International Plant Names Index 2016) e Tropicos (2016). As descrições taxonômicas foram baseadas na análise de amostras herborizadas, acrescidas das flores e frutos conservados em álcool 70\%. A terminologia usada nas descrições das espécies seguiu Hickey (1974), Hickey \& King (2000), Radford et al. (1974) e Barroso et al. (1999). O material adicional utilizado foi proveniente dos seguintes herbários: CEPEC, GUA, R, RB e RBR.

A partir dos dados obtidos através da descrição dos espécimes, foi elaboada uma chave de identificação das espécies ocorrentes no IZMA. Os dados fenológicos, de endemismo, distribuição geográfica e nomes populares foram complementados a partir da literatura (Pio Corrêa 1926, Guarim-Neto et al. 2000, Somner et al. 2009b) e de materiais de herbário.

\section{Resultados e Discussão}

Somner et al. (2015) listou 132 espécies de Sapindaceae para o Estado do Rio de Janeiro. Na área de estudo foram catalogadas 20 espécies, distribuídas em sete gêneros (tabela 1). Esse quantitativo representa aproximadamente $15 \%$ das espécies de Sapindaceae registradas para o Estado. Tamanha riqueza de espécies concentrada em um fragmento com apenas 15 ha chama a atenção, já que a tendência natural de uma área submetida à fragmentação é o empobrecimento da biodiversidade nela existente (Tabarelli et al. 2004, Oliveira et al. 2004). Apesar de não existirem estudos nos remanescentes adjacentes, a alta diversidade observada na área de estudo pode estar relacionada à conectividade desta com outras áreas florestadas maiores que compõem a região (figura 1).

É interessante relatar que neste estudo, das 20 espécies ocorrentes, 16 são exclusivas do Brasil e 10 espécies são endêmicas da Mata Atlântica (tabela 1). Também foi documentada a ocorrência de uma nova espécie recentemente descrita, Allophylus exappendiculatus Somner, Ferrucci \& Frazão, descoberta durante o desenvolvimento deste estudo florístico. Essa descoberta evidencia a necessidade de estudos adicionais em outros trechos de Floresta Estacional Semidecidual no Estado do Rio de Janeiro.

De acordo com os dados coletados, foi constatado que existem na área estudada espécies que não eram coletadas há muito no Estado do Rio de Janeiro. As lacunas amostrais verificadas para Paullinia thalictrifolia Radlk. e Serjania gracilis Radlk. correspondem, respectivamente, a 84 e 43 anos, a contar de seus últimos registros confirmados. Observou-se ainda subamostragem das espécies dos gêneros Allophylus e Matayba registradas para o IZMA no Estado do Rio de Janeiro. Estes dados estão possivelmente relacionados ao pouco investimento e esforço amostral fora de unidades de conservação, além do franco processo de fragmentação ocorrido nessa região desde a colonização européia, iniciada no século XVI (Morellato \& Haddad 2000).

Das 20 espécies registradas para a área de estudo, Sapindus saponaria L., Serjania caracasana (Jacq.) Willd., S. communis Cambess., S. lethalis A.St.-Hil. e Urvillea rufescens Cambess. são as que apresentam ampla distribuição geográfica. Já $A$. exapendicullatus Somner, Frazão \& Ferrucci, A. melanophloeus Radlk., Cupania concolor Radlk., C. furfuracea Radlk. e Matayba sylvatica (Casar.) Radlk. são restritas à região sudeste do Brasil, sendo A. exapendicullatus endêmica do Estado do Rio de Janeiro.

A importância do estudo e conservação das espécies aqui tratadas é corroborada pela observação, na área de estudo, de animais consumindo recursos disponibilizados por elas, como espécies de insetos visitando as flores e de aves consumindo o arilo e sarcotesta das sementes. Complementarmente às observações ao longo de expedições de campo, há registros da presença de grãos de pólen de espécies de Sapindaceae em méis produzidos por Apis mellifera L. na região (Luz et al. 2007). Informações acerca dos visitantes florais e consumidores dos frutos das espécies aqui tratadas estão apresentadas nos comentários das espécies. Além disso, dados adicionais sobre os tipos de dispersão dos frutos (Pij1 1972) das espécies aqui estudadas, endemismo, novidade de registro para a região, tipo de domínio fitogeográfico e fitofisionomia de ocorrência foram resumidas na tabela 1 .

A representativa riqueza de espécies da família Sapindaceae registrada ao longo do desenvolvimento deste trabalho mostra que a área de estudo é promissora no que tange à ampliação do conhecimento da biodiversidade do Estado do Rio de Janeiro. Além disso, é interessante salientar que, apesar deste trabalho apresentar a mais detalhada descrição da flora de Sapindaceae de uma localidade do Centro-Sul Fluminense até o momento, dois anos antes da publicação de Allophylus exappendiculatus por nossa equipe (Somner et al. 2013), uma nova espécie de anfíbio, Brachycephalus margaritatus (Brachycephalidae), também foi descrita para essa região (Pombal Jr. \& Izecksohn 2011). 
Esses dados sugerem que essa zona historicamente subamostrada pode albergar uma diversidade ainda não descrita de organismos da fauna e da flora, merecendo atenção especial das autoridades quanto a criação de unidades de conservação. Isso porque as espécies ali distribuídas encontram-se diretamente afetadas pela avançada fragmentação das paisagens naturais, resultante da expansão de áreas urbanas e de agronegócios nos municípios de seu entorno.

Sapindaceae Juss., A.L. de Jussieu, Ann. Mus. Natl. Hist. Nat. 18: 476. 1811.

Árvores, arbustos ou lianas; nas lianas um par de gavinhas na base da inflorescência, lactescentes ou não, caule cilíndrico, estriado, costado ou sulcado, nas lianas, em seção transversal, um único cilindro vascular, ou um cilindro vascular central e 3-10 cilindros vasculares periféricos, ou ainda lobado; estípulas presentes ou ausentes. Folhas alternas, compostas paripinadas ou imparipinadas, variando de trifolioladas, pinadas e tripinadas; estípulas presentes ou não, folíolos com margem denteadoserreada ou inteira, com ou sem domácias na face abaxial. Inflorescência axilar ou terminal, com tirso racemiforme, espiciforme ou paniculiforme, nas lianas sinflorescências frondobracteosas ou bracteosas, com tirsos racemiformes ou espiciformes; inflorescências parciais cincinos. Flores aparentemente bissexuadas,

Tabela 1. Espécies de Sapindaceae encontradas no Instituto Zoobotânico de Morro Azul (IZMA), Engenheiro Paulo de Frontin, RJ, Brasil, com respectivos hábitos, endemismo, ocorrência em domínios fitogeográficos e em fitofisionomias na Mata Atlântica e tipo de dispersão dos frutos. AM: Amazônia; CT: Caatinga; CR: Cerrado; MA: Mata Atlântica; PT: Pantanal; FOD: Floresta Ombrófila; FES: Floresta Estacional Semidecidual; RST: Restinga. *Primeiro registro da espécie para Engenheiro Paulo de Frontin, RJ, Brasil.

Table 1. Species of Sapindaceae found at the Instituto Zoobotânico de Morro Azul (IZMA), Engenheiro Paulo de Frontin, Rio de Janeiro State, Brazil, with notes on habits, endemism, phytogeographic domain and phytofisionomy of occurrence in the Atlantic Forest, and seed dispersal syndrome. AM: Amazon forest; CT: Caatinga; CR: Central Brazilian Savanna (Cerrado); MA: Atlantic Forest; PT: Pantanal; FOD: Tropical Rain Forest; FES: Seasonally Semideciduous Forest; RST: Sandy Costal Plains (Restinga). *First record of the species for Engenheiro Paulo de Frontin, Rio de Janeiro State, Brazil.

\begin{tabular}{|c|c|c|c|c|c|}
\hline Espécie & Hábito & $\begin{array}{c}\text { Endêmica do } \\
\text { Brasil }\end{array}$ & $\begin{array}{c}\text { Domínio } \\
\text { fitogeográfico }\end{array}$ & Fitofisionomia & $\begin{array}{c}\text { Tipo de } \\
\text { dispersão }\end{array}$ \\
\hline $\begin{array}{l}\text { Allophylus exapendiculatus Somner, } \\
\text { Frazão \& Ferrucci }\end{array}$ & Árvore & $\mathrm{X}$ & MA & FES & Zoocórico \\
\hline Allophylus melanophloeus Radlk.* & $\begin{array}{l}\text { Arbusto ou } \\
\text { árvore }\end{array}$ & $\mathrm{X}$ & MA & FES, FOD & Zoocórico \\
\hline Allophylus racemosus Sw.* & Arbusto & $\mathrm{X}$ & $\mathrm{AM}, \mathrm{CT}, \mathrm{CR}, \mathrm{MA}$ & FES, FOD & Zoocórico \\
\hline Cupania concolor Radlk.* & Árvore & $\mathrm{X}$ & MA & FES, FOD & Zoocórico \\
\hline Cupania furfuracea Radlk.* & Árvore & $\mathrm{X}$ & MA & FES, FOD & Zoocórico \\
\hline Cupania oblongifolia Mart. & Árvore & $\mathrm{X}$ & $\mathrm{AM}, \mathrm{CR}, \mathrm{CT}, \mathrm{MA}$ & FES, FOD, RST & Zoocórico \\
\hline Cupania racemosa (Vell.) Radlk. & Árvore & $\mathrm{X}$ & $\mathrm{CT}, \mathrm{CR}, \mathrm{MA}$ & FES, FOD, RST & Zoocórico \\
\hline Matayba sylvatica (Casar.) Radlk.* & Árvore & $\mathrm{X}$ & MA & FES, FOD & Zoocórico \\
\hline Paullinia carpopoda Cambess.* & Trepadeira & $\mathrm{X}$ & $\mathrm{CR}, \mathrm{MA}$ & FES, FOD & Zoocórico \\
\hline Paullinia meliifolia Juss.* & Trepadeira & & MA & FES, FOD, RST & Zoocórico \\
\hline Paullinia micrantha Cambess.* & Trepadeira & $\mathrm{X}$ & MA & FES, FOD, RST & Zoocórico \\
\hline Paullinia thalictrifolia Juss.* & Trepadeira & $\mathrm{X}$ & MA & FES, FOD & Zoocórico \\
\hline Sapindus saponaria L.* & Árvore & & $\mathrm{AM}, \mathrm{CT}, \mathrm{MA}, \mathrm{PT}$ & FES, FOD & $\begin{array}{l}\text { Barocórico e } \\
\text { Zoocórico }\end{array}$ \\
\hline Serjania caracasana (Jacq.) Willd.* & Trepadeira & & $\begin{array}{c}\mathrm{AM}, \mathrm{CT}, \mathrm{CR}, \mathrm{MA}, \\
\text { PT }\end{array}$ & FES, FOD & Anemocórico \\
\hline Serjania clematidifolia Cambess.* & Trepadeira & & $\mathrm{AM}, \mathrm{CR}, \mathrm{MA}$ & FES, FOD, RST & Anemocórico \\
\hline Serjania communis Cambess.* & Trepadeira & & $\mathrm{AM}, \mathrm{CR}, \mathrm{MA}$ & FES, FOD, RST & Anemocórico \\
\hline Serjania corrugata Radlk.* & Trepadeira & $\mathrm{X}$ & MA & FES, FOD, RST & Anemocórico \\
\hline Serjania gracilis Radlk.* & Trepadeira & $\mathrm{X}$ & MA & FES, FOD & Anemocórico \\
\hline Serjania lethalis A. St.-Hil.* & Trepadeira & & $\begin{array}{c}\text { AM, CT, CR, MA, } \\
\text { PT }\end{array}$ & FES, FOD & Anemocórico \\
\hline Urvillea rufescens Cambess.* & Trepadeira & $\mathrm{X}$ & MA & FES, FOD, RST & Anemocórico \\
\hline
\end{tabular}


porém unissexuadas funcionais; actinomorfas ou zigomorfas; sépalas 4-5, livres, unidas ou conatas na base; pétalas 4-5, brancas ou branco-amareladas, livres, geralmente com apêndice petaloide na face adaxial, inteiro ou bipartido, adnato à margem das pétalas ou, nas lianas, em forma de capuz, com crista carnosa, amarela no ápice, de várias formas nas duas pétalas posteriores as quais apresentam lígula deflexa na base da crista, e unilobada nas duas pétalas laterais, ambas coniventes às pétalas; nectários florais extra-extaminais anelares ou unilaterais, de formas variadas, na maioria das lianas fragmentado em 4 lobos (2 posteriores e 2 laterais); androginóforo presente ou não; estames $6-8$, livres ou conatos na base, anteras elípticas, dorsifixas, bitecas, rimosas; estaminódios 8, anteras indescentes; ovário súpero, gamocarpelar, (2-)3-carpelar, (2-)3-locular, lóculos uniovulados, placentação axial. Frutos cápsulas loculicidas ou septífragas, esquizocarpo com três mericarpos samaroides, drupáceos ou baciformes; sementes com ou sem arilo ou sarcotesta; embrião com eixo subreto ou curvo; cotilédones geralmente crassos, eixo radícula-hipocótilo curto, geralmente alojado em uma dobra do tegumento.

\section{Chave para identificação das espécies de Sapindaceae ocorrentes no IZMA}

\section{1. Árvores ou arbustos}

2. Folhas trifolioladas, com domácias pilosas na face abaxial; sépalas 4; mericarpos drupáceos com 1-2-cocos

3. Tirsos agrupados, dispostos em inter-nós muito próximos na axila das cicatrizes foliares, racemiformes, não ramificados; apêndice petaloide ausente ou vestigial; disco nectarífero prateliforme Allophylus exappendiculatus

3. Tirsos não agrupados, não dispostos em inter-nós muito próximos na axila das cicatrizes foliares, racemiformes, ramificados com 1-2 ramos basais; apêndice petaloide presente; disco nectarífero anelar lobado ou semianelar com 4 lobos

4. Tirsos com indumento branco-amarelado, hirsuto-pubescentes; folíolos com ápice agudo, obtuso, arredondado ou apiculado, margem conspicuamente serrilhada até a base, face abaxial verde-pálida, denso hirsuto-pubescente; mericarpos drupáceos sem tricomas glandulares .... Allophylus racemosus

4. Tirsos com indumento castanho, pubescente; folíolos com ápice longo-acuminado, frequentemente falciforme, raro agudo, margem subinteira ou denteado-serreada na metade distal, face abaxial castanha a castanho-escura, pubescente nas nervuras; mericarpos drupáceos com tricomas glandulares Allophylus melanophloeus

2. Folhas 3-13 folioladas, com folíolo distal rudimentar, em forma de apículo, domácias foveoladas, urceoladas ou ausentes na face abaxial; sépalas 5; mericarpos baciformes com 1-2 cocos ou cápsulas loculicidas

5. Pecíolo frequentemente alado; folíolos sem domácias na face abaxial; mericarpos baciformes com 1-2-cocos Sapindus saponaria

5. Pecíolo não alado; folíolos com domácias na face abaxial; cápsula loculicida

6. Folíolos com margem inteira não ondulada; apêndice petaloide fendido medialmente até a base da unha, atingindo o comprimento da pétala; cápsula subglobosa, com endocarpo densamente branco-lanoso Matayba sylvatica

6. Folíolos com margem inteira ondulada, denteado-serreada ou inciso-denteada; apêndice petaloide fendido medialmente até a base da unha, menor do que comprimento da pétala; cápsula não subglobosa, sem endocarpo densamente branco-lanoso

7. Margem dos folíolos conspicuamente inciso-denteada; face abaxial dos folíolos ferrugíneo-tomentosa, com tricomas escabrosos enegrecidos dispersos na lâmina; cápsula trilobado-obovoide

7. Margem dos folíolos inteira, ondulada ou denteado-serreada; face abaxial dos folíolos glabra, pubérula ou glabrescente, sem tricomas escabrosos; cápsula trígono-piriforme, trilobada-obovoide ou trialado-obovoide

8. Cápsula trígono-piriforme, com epicarpo glabro e com lenticelas esbranquiçadas ou amareladas Cupania oblongifolia

8. Cápsula 2-3-lobado-obovoide ou trialado-obovoide, com epicarpo pubérulo, estrigoso, glabrescente ou tomentoso e sem lenticelas esbranquiçadas ou amareladas 
9. Face adaxial dos folíolos lustrosa; anteras amareladas; cápsula amarelada a avermelhada, 2-3-lobado-obovoide, epicarpo pubérulo, depois glabrescente

Cupania concolor

9. Face adaxial dos folíolos opaca; anteras vináceas; cápsula castanha, trialadoobovoide, epicarpo tomentoso, depois glabrescente

Cupania racemosa

1. Lianas com gavinhas

10. Cápsula septífraga

11. Caule trilobado; folhas trifolioladas; anteras purpúreas; cápsula com a porção central inflada

Urvillea rufescens

11. Caule cilíndrico ou subcilíndrico; folhas pinadas 5-folioladas, 11-folioladas ou 13-folioladas com um par de folíolos basais trifoliolados, biternadas ou tripinadas; anteras amarelas; cápsula sem porção central inflada

12. Folhas tripinadas, face adaxial às vezes com manchas esbranquiçadas no centro dos foliólulos, tricomas setosos dispersos próximos à margem; cápsula com epicarpo amarelo-tomentoso Paullinia thalictrifolia

12. Folhas 11 ou 13-folioladas, um par de folíolos basais trifoliolulados, face adaxial sem manchas esbranquiçadas no centro dos folíolos, sem tricomas setosos dispersos próximos à margem; cápsula com epicarpo glabro

13. Folíolos com margem inteira, pecíolo alado; cápsula globosa 6-costada, não alada, crustácea Paullinia carpopoda

13. Folíolos com margem denteado-serreada; pecíolo não alado; cápsula trialadoobovoide, subcoriácea

14. Caule cilíndrico; estípulas triangulares; cápsula com endocarpo tomentoso; cotilédone externo curvo e o interno biplicado Paullinia micrantha

14. Caule subcilíndrico; estípulas falciformes; cápsula com endocarpo denso-lanoso; cotilédones subretos

Paullinia meliifolia

10. Mericarpos samaroides, 3

15. Caule em seção transversal com apenas um cilindro vascular

Serjania gracilis

16. Caule com um cilindro vascular central muito reduzido e cinco cilindros vasculares radialmente dispostos, tricomas glandulares alaranjados dispersos no caule ..... Serjania corrugata

16. Caule com um cilindro vascular central não reduzido e 3-10 cilindros vasculares periféricos menores, mas não radialmente dispostos, sem tricomas glandulares alaranjados dispersos

17. Caule composto por 7-10 cilindros vasculares periféricos

18. Caule 9-10-sulcado, sulcos conspícuos, epicarpo tomentoso; margem dos folíolos crenado-serreados; porção seminífera do mericarpo subglobosa, côncava na porção lateral de cada mericarpo Serjania clematidifolia

18. Caule 7-8-costado, epicarpo glabro; margem dos folíolos denteado-serreada; porção seminífera do mericarpo obovada, sem concavidade na porção lateral de cada mericarpo

Serjania caracasana

17. Caule composto por 3-5 cilindros vasculares periféricos

19. Caule triangular, 3-costado, tomentoso, em seção transversal com 3 cilindros periféricos equidistantes; mericarpos samaróides com a porção seminífera do mericarpo achatada lateralmente e com crista dorsal presente; sementes lenticulares; cotilédones subretos Serjania communis

19. Caule subcilíndrico, não costado, glabro, em seção transversal com 3-4 (5) cilindros periféricos, quando mais de 3 , dispostos aos pares; mericarpos samaróides com a porção seminífera do mericarpo globosa; crista dorsal ausente; sementes subglobosas; cotilédone externo curvo e interno biplicado Serjania lethalis 
Allophylus exappendiculatus Somner, Frazão \&

Ferrucci, Ann. Bot. Fennici 50: 402. 2013.

Figura 2d

Árvores de 3-9 m alt. Ramos pouco verrucosos, glabros. Folhas trifolioladas, 6-28,5 cm compr.; pecíolos cilíndricos, levemente constritos na base; folíolos 3,7-17,5 × 2,9-8 cm, cartáceos, estreitoovados, estreito-elípticos ou subromboidais, os laterais de tamanho semelhante aos terminais; ápice longo acuminado, frequentemente falciforme; base cuneada, decurrente ou assimétrica; margem dentado-serreada; concolores, glabros em ambas as faces, exceto com tricomas esparsos nas nervuras principais, com domácias pilosas. Tirsos espiciformes, 4-10,9 cm compr., agrupados em inter-nós muito próximos na axila das cicatrizes foliares, não ramificados, indumento esbranquiçado, pubescente; cincinos 2-6-floros; pedicelos ca. 2,5 mm compr; brácteas ca. $2 \mathrm{~mm}$ compr., ovado-triangulares, bractéolas ca. $1 \mathrm{~mm}$ compr., triangulares. Flores com sépalas 4, 1-1,5 × 1-2 mm, subcartáceas, obovadas ou orbiculares, glabras externa e internamente, ciliadas; pétalas 4, brancas, $1-2 \times 0,6-1 \mathrm{~mm}$, obovadas, unguiculadas, ápice arredondado ou emarginado, desprovidas de apêndice petaloide bipartido basal ou este vestigial; disco nectarífero anelar, prateliforme; androginóforo ausente; estames 6-8, quando 7, 1 reduzido, 2,5-3 $\mathrm{mm}$ compr., pubescentes no terço basal; anteras amareladas, glabras; ovário bilobado, 2-carpelar, adpresso-pubescente; estilete ca. 1,2 mm compr.; estigma bilobado. Mericarpos drupáceos, coloração desconhecida, carnosos, ca. $0,7 \times 0,5-0,6 \mathrm{~cm}, 2$-cocos obovóides, glabros; sementes obovoides; embrião com cotilédone externo curvo e interno biplicado.

Material examinado: BRASIL. Rio DE JANEIRo: Engenheiro Paulo de Frontin, Instituto Zoobotânico de Morro Azul, 26-VIII-2009, bt., A.F. Nunes 38 (RBR). 7-IX-2009, fl. masc., A.F. Nunes 42 (RBR). 30-V-2010, st, A.F. Nunes 67 (RBR). 27-VIII-2010, fl. masc., A.F. Nunes 96 (RBR).

Material adicional examinado: BRASIL. RIO DE JANEIRO: Itaguaí, Serra do Caçador, s.d., fl. fem. e masc., fr., J. Lobão 491 (RB).

Distribuição geográfica: a espécie é endêmica do Estado do Rio de Janeiro, tendo registro apenas para os municípios de Engenheiro Paulo de Frontin, Itaguaí e Santa Maria Madalena.
Esta espécie difere das demais do gênero resgistradas na área de estudo por apresentar os tirsos dispostos em inter-nós muito próximos à axila das cicatrizes foliares, flores com pétalas sem apêndice petaloide basal ou com este vestigial, disco nectarífero anelar, prateliforme, androceu constituído por 6 a 8 estames (quando 7, um deles é reduzido) e drupas glabras. A espécies foi coletada com flores nos meses de agosto e setembro. Durante as expedições de campo, foi observada a presença de abelhas e borboletas visitando os indivíduos desta espécie durante o período de floração. Outra característica fenológica observada foi a senescência das folhas no período de pré-floração.

Allophylus melanophloeus Radlk. in Mart., Fl. bras. 13(3): 478. 1900.

Figura 2a-c

Árvore de até $9 \mathrm{~m}$ alt. Ramos estriados, pubescentes, depois glabrescentes. Folhas trifolioladas, 5,3-25 cm compr.; pecíolos cilíndricos; folíolos 2,6-15 $\times 0,8-3,3 \mathrm{~cm}$, cartáceos, elípticos, elíptico-oblongos, elíptico-lanceolados ou estreito-obovados, os laterais de tamanho semelhantes aos terminais; ápice longoacuminado, raro agudo, frequentemente falciforme; base cuneada, atenuada ou assimétrica; margem subinteira ou denteado-serreada; discolores, face adaxial enegrescida quando secos os folíolos, às vezes lustrosa, face abaxial castanha mais clara que a adaxial, subglabra a pubescente e com tricomas glandulares sobre a nervura principal, com domácias pilosas. Tirso racemiforme, 3,6-6,2 cm compr., não agrupado, não ramificado ou podendo apresentar 1-2 ramos basais, indumento castanho, pubescente; cincinos 3-4-floros; pedicelo 1-3 mm compr.; brácteas 1-1,5 mm compr., subuladas, bractéolas ca. $1 \mathrm{~mm}$ compr., subuladas. Flores com sépalas 4, 2-5 × 1-2 mm, cartáceas, oblongas ou obovadas, glabras ou subglabras externamente, glabras internamente, ciliadas; pétalas 4, branco-amareladas, 1-2 mm compr., espatuladas a flabeliformes, unguiculadas, ápice irregular, truncado, pubescente, apêndice petaloide bipartido, fendido medialmente até a parte inicial da unha, formando duas linguetas denso-vilosas, deflexas, menores do que a pétala; disco nectarífero semianelar, com 4 lobos subretangulares; androginóforo ausente; estames 8, 1,8-3 mm compr., vilosos; anteras amareladas, glabras; ovário obovóide, 2-3-carpelar, pubescente; estilete ca. $1 \mathrm{~mm}$ compr.; estigma bilobado ou trilobado. Mericarpos drupáceos, alaranjados ou avermelhados, carnosos, 0,8-1 × 0,6-0,9 cm, 1-2-cocos obovoides, 


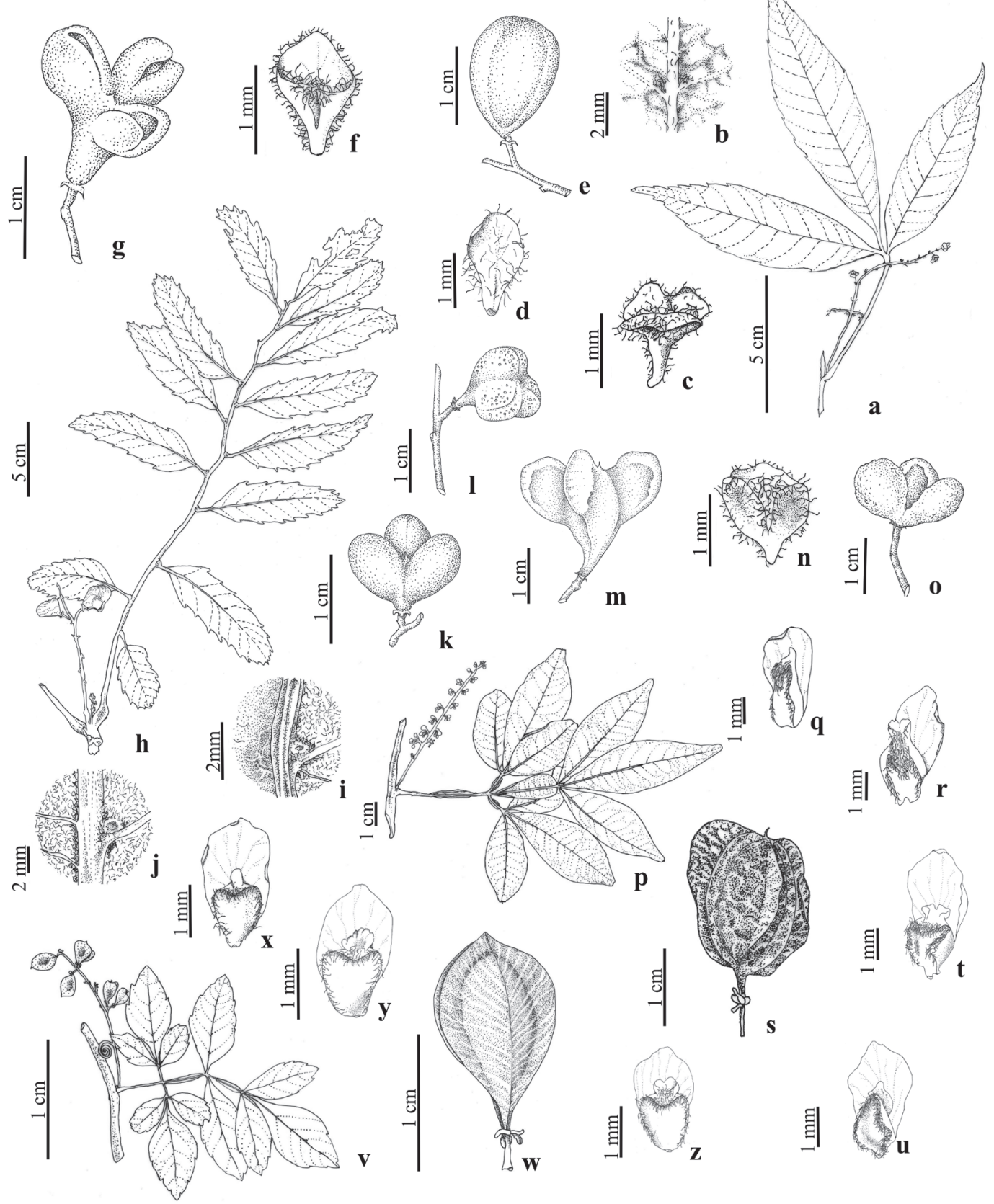

Figura 2. a-c. Allophylus melanophloeus. a. Folha e inflorescência. b. Domácia pilosa. c. pétala. d. Allophylus exappendiculatus. Pétala. e. Allophylus racemosus. Fruto. f-g. Cupania concolor. f. Pétala. g. Fruto. h-j. Cupania furfuracea. h. Folha e infrutescência. i. Domácia foveolada. j. Domácia urceolada. k. Fruto. 1. Cupania oblongifolia. Fruto. m. Cupania racemosa. Fruto. n-o. Matayba sylvatica. n. Pétala. o. Fruto. p-r. Paullinia carpopoda. p. Folha e inflorescência. q. Pétala lateral. r. Pétala posterior. s-u. Paullinia meliifolia. s. Fruto. t. Pétala posterior. u. Pétala lateral. v-z. Paullinia micrantha. v. Folha e infrutescência. w. Fruto. x. Pétala lateral. y. Pétala posterior erosa. z. Pétala posterior emarginada.

Figure 2. a-c. Allophylus melanophloeus. a. Leaf and inflorescence. b. Hairy domatia. c. Petal. d. Allophylus exappendiculatus. Petal. e. Allophylus racemosus. Fruit. f-g. Cupania concolor. f. Petal. g. Fruit. h-j. Cupania furfuracea. h. Leaf and infructescence. i. Foveolate domatia. j. Urceolate domatia. k. Fruit. 1. Cupania oblongifolia. Fruit. m. Cupania racemosa. Fruit. n-o. Matayba sylvatica. n. Petal. o. Fruit. p-r. Paullinia carpopoda. p. Leaf and inflorescence. q. Lateral petal. r. Posterior petal. s-u. Paullinia meliifolia. s. Fruit. t. Posterior petal. u. Lateral petal. v-z. Paullinia micrantha. v. Leaf and infructescence. w. Fruit. x. Lateral petal. y. Posterior erose petal. z. Posterior emarginate petal. 
com tricomas glandulares; sementes oblongas; embrião com cotilédone externo curvo e interno biplicado.

Material examinado: BRASIL. Rio DE JANEIRo: Engenheiro Paulo de Frontin, Instituto Zoobotânico de Morro Azul, 27-XI-2010, fl. masc., A.F. Nunes 105 (RBR).

Material adicional examinado: BRASIL. RIo DE JaneIro: Paraty, 8-VIII-1994, fr, $R$. Marquete 1968 (RB). Teresópolis, 5-II-1998, fl. fem., C.A.L. Oliveira 1431 (GUA).

Distribuição geográfica: ocorre nos Estados de Minas Gerais, Rio de Janeiro e São Paulo.

Nomes populares: cucum, fruta-de-paraó, fruta-dopombo, pé-de-galinha, três-folhas-do-mato.

A espécie é distinguível das demais do gênero na área de estudo por apresentar folíolos discolores com margem subinteira ou denteado-serreada. Quando secos, os folíolos possuem face adaxial enegrescida e às vezes lustrosa. As flores possuem disco nectarífero em forma de hemidisco 4-lobado subretangulares e apêndice petaloide bipartido, fendido medialmente até a parte inicial da unha, sendo que o ápice forma duas linguetas deflexas e denso vilosas, menores que a pétala. As drupas são pubescentes. A espécie foi registrada com flores em novembro e, assim como A. exappendiculatus, foi observada a presença de abelhas e borboletas visitando as flores nos períodos de floração.

Allophylus racemosus Sw., Prodr. 62. 1788. Figura 2e

Árvores ou arbustos de 3-8 m alt. Ramos estriados, hirsuto-pubescentes, depois glabrescentes. Folhas trifoliodadas, 7,3-27,5 cm compr.; pecíolos cilíndricos; folíolos 2,8-17,7 × 1-8,5 cm, cartáceos, discolores, ovados, ovado-lanceolados, obovados ou elípticos, os laterais de tamanho semelhante ou menores que os terminais; ápice agudo, obtuso, arredondado ou apiculado; base atenuada, cuneada ou assimétrica; margem conspicuamente serrilhada até a base; discolores, face adaxial verde, hirsuto-pubescente nas nervuras, face abaxial verde-amarelada, denso hirsutopubescente, mais pilosa nas nervuras, com domácias pilosas. Tirso racemiforme, 2,8-5,7 cm compr., não agrupados, não ramificados, indumento brancoamarelado, hirsuto-pubescente; cincino 1-3(4)-floros; pedicelo floral 0,5-1 mm compr.; brácteas e bractéolas ca. $1 \mathrm{~mm}$ compr., triangulares. Flores com sépalas 4 ,
1-1,5 × 1-1,5 mm, cartáceas, elípticas ou orbiculares, pubescentes externa e internamente, ciliadas; pétalas 4, brancas, 1,5-2,5 mm compr., unguiculadas, espatuladas, apêndice petaloide bipartido, fendido medialmente até a parte inicial da unha, formando duas linguetas vilosas, deflexas, menores do que a pétala; disco nectarífero em forma de hemidisco 4-lobado, 2 posteriores subretangulares e 2 anteriores quadrangulares; androginóforo ausente; estames 8, 2-3 mm compr., seríceos no terço basal; anteras amareladas, glabras; ovário globoso, 2-carpelar, denso-pubescente; estilete ca. $0,5 \mathrm{~mm}$ compr.; estigma bilobado. Mericarpos drupáceos, amarelados ou alaranjados, carnosos, 1-1,2 × 0,7-1 cm, 1-2-cocos obovoides, pubescentes; sementes oblongas; embrião com cotilédone externo curvo e interno biplicado.

Material examinado: BRASIL. RIo DE JANEIRO: Engenheiro Paulo de Frontin, Instituto Zoobotânico de Morro Azul, 26-VIII-2009, bt, A.F. Nunes 37 (RBR). 7-IX-2009, fl. masc., A.F. Nunes 44 (RBR).

Material adicional examinado: BRASIL. RIO DE JaneIro: Teresópolis, 16-XI-2000, fr., C.S. Pardo 136 (RBR). Nova Iguaçú, 14-IX-2001, fl. fem., S.J. Silva-Neto 1479 (RBR). São Paulo: Guaratinguetá, 29-VIII-1995, fr., D.C. Cavalcanti 189 (RBR).

Distribuição geográfica: espécie com distribuição neotropical. No Brasil, está distribuída pelos Estados da Bahia, Ceará, Distrito Federal, Espírito Santo, Goiás, Maranhão, Minas Gerais, Pará, Paraíba, Pernambuco, Piauí, Roraima, Rio de Janeiro, São Paulo e Tocantins.

Nomes populares: laranjeira-do-mato e pau-pombo.

Allophylus racemosus difere das outras duas espécies do gênero registradas na área de estudo por apresentar ramos estriados, hirsuto-pubescentes, face abaxial dos folíolos verde-amarelada, denso hirsutopubescente e drupas pubescentes. Esta espécie foi coletada com flores no período de agosto a novembro.

Cupania concolor Radlk. in Mart., Fl. bras. 13(3): 587. 1900.

Figura 2f, $g$

Árvores de 3-8 m alt. Ramos sulcados, denso-tomentosos, depois glabros. Folhas (3-4) 6-13-folioladas, 4,6-16 cm compr., com folíolo distal rudimentar, em forma de apículo; pecíolo cilíndrico; folíolos 3-10 × 0,9-2,6 cm, cartáceos ou subcoriáceos, estreito-elípticos, ovado-lanceolados ou estreito-oblongos; ápice agudo, obtuso ou retuso; base atenuada ou assimétrica; margem denteado- 
serreada; discolor face adaxial lustrosa, glabra, face abaxial opaca, glabra ou pubescente, com domácias foveoladas. Tirso racemiforme ou paniculiforme, 3,3-13,2 compr., indumento castanho-amarelado, denso-pubescente; pedicelo ca. $1 \mathrm{~mm}$ compr.; brácteas 0,8-2,5mm compr., subuladas, bractéolas $0,7-1 \mathrm{~mm}$ compr., subuladas; Flores com sépalas 5, 1-3,5 × 1-1,5 $\mathrm{mm}$, subcoriáceas, ovadas ou oblongas, tomentosas, ciliadas; pétalas 5, branco-amareladas, 1,5-2,5 × 1,5-2 $\mathrm{mm}$, obovadas, longamente unguiculadas, apêndice petaloide bipartido, fendido medialmente até a extremidade da unha, tomentoso; disco nectarífero anelar, lobado; androginóforo ausente; estames 8, 1,5-3 mm compr., vilosos; anteras amarelas, glabras; ovário trilobado-ovóide, 2-3-carpelar, denso-ferrugíneotomentoso; estilete ca. $1 \mathrm{~mm}$ compr.; estigma clavado. Cápsula loculicida amarelada a avermelhada, coriácea, 1,2-2,3 × 1-1,8 cm, 2-3-lobada-obovoide, epicarpo ferrugíneo-pubérulo, depois glabrescente, endocarpo denso-ferrugíneo, lanoso; sementes elipsoides ou obovóides, arilo amarelado até a metade da semente; embrião com cotilédones notorrizos.

Material examinado: BRASIL. Rio DE JANeIRo: Engenheiro Paulo de Frontin, Instituto Zoobotânico de Morro Azul, 12-VII-2009, fr., A.F. Nunes 39 (RBR). 30-IV-2010, fl. fem. e masc., A.F. Nunes 52 (RBR). 6-VIII-2010, fr., A.F. Nunes 90 (RBR).

Material adicional examinado: BRASIL. RIo DE JANEIRO: Paraty, 20-III-1992, fl. masc., M.C. Marquês 265 (RBR).

Distribuição geográfica: ocorre nos Estados de Minas Gerais, Rio de Janeiro e São Paulo.

Cupania concolor é distinta das outras espécies do gênero encontradas na área de estudo pela presença de folhas com a face adaxial lustrosa, apêndice petaloide bipartido das pétalas tomentoso e fendido medialmente até a extremidade da unha e por apresentar cápsulas amareladas a avermelhadas, 2-3-lobado-obovoides, ferrugíneo-pubérulas, depois glabrescentes. Ao longo da realização deste trabalho a espécie floresceu de março a junho e frutificou de julho a dezembro. Ao longo das expedições de campo, foram observados indivíduos contendo frutos jovens com galhas e diversos pássaros consumindo o arilo das sementes desta espécie.

Cupania furfuracea Radlk., Sitzungsber. Math.-Phys. Cl. Königl. Bayer. Akad. Wiss. München 9:567. 1879. Figura $2 \mathrm{~h}-\mathrm{j}$

Árvores de 3-10 m alt. Ramos sulcados, lanosotomentosos, depois glabrescentes. Folhas 8-10 folíoladas, 23-36 cm compr.; folíolo distal rudimentar, em forma de apículo; pecíolo cilíndrico; folíolos 2-20,5 × 0,8-4,6 cm, coriáceos, elípticos, oblongolanceolados, estreito-oblongos, ovados, estreitoovados; ápice agudo, raro retuso; base cuneada, atenuada ou assimétrica; margem conspicuamente inciso-denteada; discolores, face adaxial verde-escura, glabra, face abaxial ferrugíneo-tomentosa, com tricomas escabrosos enegrecidos dispersos na lâmina, depois glabrescentes, com domácias urceoladas, raro foveoladas. Tirso racemiforme ou paniculiforme, 7,9-15,8 cm compr., indumento ferrugíneo, densotomentoso; pedicelo ca. $1 \mathrm{~mm}$ compr.; brácteas 1-2 mm compr., lanceolado-subuladas, bractéolas 0,5-1 mm compr., lanceolado-subuladas. Flores com sépalas 5, 1,5-2,2 mm, coriáceas, ovadas, tomentosas, ciliadas; pétalas 4 , branco-amareladas, 2-2,5 × 1,5-1,6 mm, obovadas, unguiculadas, apêndice petaloide bipartido, quase nulo; disco nectarífero anelar, lobado, androginóforo ausente; estames 8, 2,2-4 mm compr., vilosos no terço basal; anteras amareladas, glabras; ovário trígono-obovóide, 3-carpelar, denso-ferrugíneo, lanoso-tomentoso; estilete ca. $1 \mathrm{~mm}$ compr.; estigma trilobado ou subclavado. Cápsula loculicida, castanho-ferrugínea, coriácea, 1-1,8 × 0,8-1,9 cm, trilobado-obovoide, epicarpo denso-tomentoso, endocarpo denso-hirsuto; sementes obovoides, arilo amarelado ou alaranjado recobrindo dois terços da semente; embrião com cotilédones plano-convexos.

Material examinado: BRASIL. RIo DE JANEIRO: Engenheiro Paulo de Frontin, Instituto Zoobotânico de Morro Azul, 23-V-2009, bt., A.F. Nunes 10 (RBR). 23-V-2009, fr., A.F. Nunes 21 (RBR). 26-VIII-2009, fr. jov., A.F. Nunes 36 (RBR). 30-IV-2010, bt., A.F. Nunes 59 (RBR). 13-VI-2010, fl. fem. e masc., A.F. Nunes 71 (RBR). 13-VI-2010, fl. fem. e masc., A.F. Nunes 73 (RBR). 15-VII-2010, fl. fem., A.F. Nunes 77 (RBR). 15-VII-2010, fl. fem. e masc., A.F. Nunes 83 (RBR). 27-XI-2010, fr., A.F. Nunes 99 (RBR). 27-XI-2010, fr., A.F. Nunes 103 (RBR).

Material adicional examinado: BRASIL. RIO DE JANEIRo: Rio de Janeiro, 30-V-2001, fl. fem., C.A.L. Oliveira 1822 (RBR).

Distribuição geográfica: ocorre nos Estados da Bahia, Espírito Santo, Rio de Janeiro e São Paulo.

Distingue-se das outras espécies do gênero na área de estudo pela presença de folíolos coriáceos com margem conspicuamente inciso-denteada, face abaxial ferrugíneo-tomentosa com tricomas escabrosos 
enegrecidos dispersos na lâmina, com domácias urceoladas, raro foveoladas, apêndice petaloide das pétalas quase nulo e cápsulas castanho-ferrugíneas, trilobado-obovoides, com epicarpo denso-tomentoso. A floração ocorre de maio a agosto e a frutificação de setembro a dezembro.

Cupania oblongifolia Mart., Flora 21(2), Beibl. 4: 67. 1838.

Figura 21

Árvores de 5-10 m alt. Ramos sulcados, pulverulento-pubescentes, depois glabrescentes. Folhas 8-12 folíoladas, 7-35,5 cm compr., folíolo distal rudimentar, em forma de apículo; pecíolo subcilíndrico; folíolos 3-17,3 × 2-8 cm, cartáceos ou subcoriáceos, obovados, elípticos, oblongos; ápice arredondado, retuso ou truncado; base cuneada ou atenuada; margem inteira, ondulada ou denteadoserreada; folíolos quando secos discolores, face adaxial verde-escura e cinescente, face abaxial castanho-esverdeada, ambas as faces glabras, com domácias foveoladas. Tirso racemiforme ou paniculiforme, 7,5-28 cm compr., indumento brancopubescente; pedicelo 0,5-1,5 mm compr.; brácteas 2-3 mm compr., elíptico-lanceoladas, bractéolas 1-1,5 mm compr., elíptico-lanceoladas. Flores com sépalas $5,2-3,5 \times 2-3 \mathrm{~mm}$, subcoriáceas, ovadas ou suborbiculares, adpresso-tomentoso, ciliadas; pétalas 5, branco-amareladas, 2-5 × 1,5-3 mm, obovadas, unguiculadas, apêndice petaloide bipartido, fendido medialmente até a base da unha, atingindo dois terços do comprimento da pétala, ferrugíneo-tomentoso; disco nectarífero anelar, lobado; androginóforo ausente; estames 8, 2-6 mm compr., tomentosos; anteras amarelas, glabras; ovário trígono-obovóide, 3-carpelar, tomentoso; estilete 2-2,5 mm compr.; estigma 3-lobado. Cápsula loculicida, castanha, coriácea, 1,7-3 × 1-2,5 cm, trígono-piriforme, epicarpo glabro, com lenticelas esbranquiçadas ou amareladas, endocarpo amarelo tomentoso; sementes obovoides, arilo alaranjado recobrindo a metade semente; embrião com cotilédones plano-convexos.

Material examinado: BRASIL. Rio DE JANEIRo: Engenheiro Paulo de Frontin, Instituto Zoobotânico de Morro Azul, 20-XII-2008, fr., G.V. Somner 1269 (RBR). 1-V-2009, fl. masc., G.V. Somner 1321 (RBR). 17-IV-2010, fl.masc., A.F. Nunes 49 (RBR). 30-V-2010, fl., A.F. Nunes 65 (RBR). 27-XI-2010, fr., A.F. Nunes 108 (RBR).

Distribuição geográfica: ocorre nos Estados do Amapá, Alagoas, Bahia, Espírito Santo, Minas Gerais,
Pará, Paraíba, Paraná, Pernambuco, Piauí, Rio de Janeiro, Rio Grande do Norte, Rio Grande do Sul, Santa Catarina e São Paulo.

Nomes populares: camboatá-de-folha-larga, camboatã, cuvantã, cantigueiro-grado, miguel-pintado-debranco, camboatá, pau d'arco branco, pau-de-espeto, camboatá-grande.

Diferente das outras espécies de Cupania do IZMA, apresenta folíolos glabros, com margem variando de inteira ondulada a denteado-serreada, anteras amarelas e cápsulas e cápsulas castanhas trígono-piriformes com epicarpo glabro e lenticelas esbranquiçadas ou amareladas. Foi registrada a floração dessa espécie de abril a julho e a frutificação de agosto a dezembro. Diversas espécies de aves foram observadas consumindo o arilo das sementes desta espécie na área de estudo, como Dacnis cayana (Linnaeus, 1766), Pachyramphus polychopterus (Vieillot, 1818), Penelope obscura (Temminck, 1815) e Turdus flavipes (Vieillot, 1818).

Cupania racemosa (Vell.) Radlk., Sitzungsber. Math. -Phys. Cl. Königl. Bayer. Akad. Wiss. Münechen 9: 568. 1879.

Figura $2 \mathrm{~m}$

Árvores de 5-12 m alt. Ramos sulcados, tomentosos, depois glabros. Folhas 6-12 folioladas, 10-28,5 cm compr., pecíolos cilíndricos; folíolos 2,3-13 × 1,4-5,2 cm, cartáceos ou subcoriáceos, elípticos, lanceolados, oblongos ou ovados; ápice agudo, obtuso ou retuso; base cuneada ou assimétrica; margem denteado-serreada; discolores, face adaxial verde-escura, opaca, glabra, abaxial verde-clara, pubérula ou glabrescente, com domácias foveoladas. Tirso racemiforme ou paniculiforme, $5,5-12 \mathrm{~cm}$ compr., indumento branco-amarelado, tomentoso; pedicelo 0,5-1 mm compr.; brácteas 2-3 mm compr., elíptico-lanceoladas, bractéolas ca. de $2 \mathrm{~mm}$ compr., elíptico-lanceoladas. Flores com . sépalas 5, 1,5-2 $\times 1,5-2 \mathrm{~mm}$, cartáceas, ovadas ou orbiculares, tomentosas, ciliadas; pétalas 5 , branco-amareladas, 2-2,5 × 1,5-2 mm, obovadas, unguiculadas, apêndice petaloide bipartido, fendido medialmente até a metade da unha, atingindo dois terços do comprimento da pétala, viloso; disco nectarífero anelar, lobado; androginóforo ausente; estames 8, 3-4,5 mm compr., vilosos; anteras vináceas, glabras; ovário trígonoobovóide, 3-carpelar, tomentoso; estilete 1-1,5 mm compr.; estigma 3-lobado. Cápsula loculicida, castanha, coriácea, 2-3 × 1,5-2,5 cm, trialado- 
obovoide, epicarpo tomentoso, depois glabrescente, endocarpo subhirsuto; sementes elipsoides, arilo alaranjado recobrindo dois terços da semente; embrião com cotilédones plano-convexos.

Material examinado: BRASIL. Rio DE JANEIRo: Engenheiro Paulo de Frontin, Instituto Zoobotânico de Morro Azul, 1-V-2009, fl. masc., G.V. Somner 1322 (RBR). 1-V-2009, fl. fem., G.V. Somner 1323 (RBR). 23-V-2009, fl. fem. e masc., A.F. Nunes 22 (RBR). 6-VIII-2009, fr., A.F. Nunes 25 (RBR). 7-IX-2009, fr. jov., A.F. Nunes 43 (RBR). 30-IV-2010, fl. fem., A.F. Nunes 51 (RBR). 30-IV-2010, fl. fem. e masc., A.F. Nunes 55 (RBR). 23-X-2010, fr., A.F. Nunes 92 (RBR). 27-XI-2010, fr., A.F. Nunes 101 (RBR).

Distribuição geográfica: ocorre nos Estados de Alagoas, Bahia, Espírito Santo, Minas Gerais, Paraíba, Pernambuco, Rio de Janeiro, Rio Grande do Norte e Sergipe.

Nomes populares: caguatan, cragoatan, cuvatan, camboatá-de-capueira e cambatam-preta.

Distingue-se das outras espécies de Cupania amostradas neste estudo pela presença de folíolos com face adaxial opaca, anteras vináceas e cápsulas castanhas, trialado-obovoides com epicarpo tomentoso, depois glabrescente. Foi registrada com flores entre os meses de março e junho e com frutos entre julho e dezembro. Ao longo das expedições de campo, foi registrado o consumo dos arilos das sementes desta espécie por diversas aves, sendo algumas as mesmas observadas para C. oblongifolia.

Matayba sylvatica (Casar.) Radlk., Sitzungsber. Math. -Phys. Cl. Königl. Bayer. Akad. Wiss. Münechen 9: 631. 1879.

Figura 2n-o

Árvores de 6-13 m alt. Ramos cilíndricos, glabros. Folhas 3-9-folioladas, 7,5-29 cm compr., com folíolo distal rudimentar em forma de apículo; pecíolo cilíndrico; folíolos 4-10,5 × 1-3,1 cm, cartáceos, elíptico-lanceolados, elíptico-oblongos, oblanceolados; ápice agudo ou cuspidado; base cuneada ou assimétrica; margem inteira; discolores, face adaxial verde-escura, glabra, face abaxial verde-clara, glabra, com domácias foveoladas. Tirso paniculiforme, 7-10 cm compr., indumento esbranquiçado, pubescente; pedicelo ca. $2 \mathrm{~mm}$ compr.; brácteas ca. 1,5 $\mathrm{mm}$ compr., triangular-lanceoladas, bractéolas ca. $1 \mathrm{~mm}$ compr., triangular-lanceoladas. Flores com sépalas 5, 1-1,5 mm compr., subcoriáceas, ovadas ou ovado-triangulares, pubérulas, ciliadas; pétalas 5, brancas, 1-1,5 mm compr., obovadas, curto unguiculadas, apêndice petaloide bipartido, fendido medialmente até a base da unha, atingindo o comprimento da pétala, denso viloso; disco nectarífero anelar, lobado; androginóforo ausente; estames 8, 1,5-3 mm compr., denso pubescente; anteras amareladas, glabras; ovário ovoide-globoso ou ovoide-elipsóide, 2-3-carpelar, denso-pubescentes; estilete ca. 1,5 mm compr.; estigma trilobado. Cápsula loculicida, alaranjada a avermelhada, coriácea, 1-2 × 1-1,2 cm, subglobosa, epicarpo estrigiloso, depois glabrescente, endocarpo densamente branco-lanoso; sementes oblongas a obovoides, arilo branco recobrindo a metade da semente; embrião com cotilédones planoconvexos.

Material examinado: BRASIL. Rio DE JANEIRo: Engenheiro Paulo de Frontin, Instituto Zoobotânico de Morro Azul, 30-IV-2010, st., A.F. Nunes 57 (RBR). 27-XI-2010, fr., A.F. Nunes 97 (RBR). 27-XI-2010, fr., A.F. Nunes 102 (RBR).

Material adicional examinado: BRASIL. RIO DE JANEIRO: Rio de Janeiro, Estrada de Furnas, próximo à bifurcação com a estrada da Vista Chinesa, 9-X-1997, fl. fem. e masc., D. Araújo 10586 (GUA). 18-XI-1997, fr., D. Araújo 10597 (GUA).

Distribuição geográfica: ocorre nos Estados do Espírito Santo e Rio de Janeiro.

Nomes populares: camboatá-do mato, camboatá-açu.

É possível distinguir Matayba sylvativa das outras espécies arbóreas do IZMA pela presença de folíolos elíptico-lanceolados, elíptico-oblongos ou oblanceolados, com margem inteira, apêndice petaloide atingindo o comprimento da pétala e pelas cápsulas alaranjadas a avermelhadas, subglobosas, com epicarpo estrigiloso, depois glabrescente e endocarpo densamente branco-lanoso. Foi coletada com frutos em novembro.

Paullinia carpopoda Cambess. in A. St.-Hil., Fl. Bras. Merid. 1: 376, pl. 78, f. B. 1828.

Figura 2p-s

Lianas lactescentes. Caule cilíndrico, pubescente, em seção transversal com apenas um cilindro vascular. Folhas biternadas ou pinadas, 11 ou 13-folioladas, folíolos basais 3-foliolulados; pecíolos bicanaliculados ou alados; estípulas 1-1,5 mm compr., ovado-lanceoladas, adpresso-tomentosas; folíolos 1,4-7,4 × 0,9-2,4 cm, subcoriáceos, elípticos, 
lanceolados ou oblanceolados; ápice agudo ou acuminado, mucronado; base aguda ou cuneada; margem inteira; discolores, face adaxial verde-escura e castanha próxima a nervura principal, pubérula apenas nas nervuras principais, face abaxial verde opaca, pubescente, com domácias pilosas. Tirso racemiforme, 9,6-14,5 cm compr., indumento amarelado, pubescente; cincinos 3-6-floros; pedicelo 1,5-2 mm compr.; brácteas $0,5-1 \mathrm{~mm}$ compr., triangulares, bractéolas ca. $0,5 \mathrm{~mm}$ compr., triangulares. Flores com sépalas 4, subcoriáceas, externas 1-2,5 mm compr., ovadas, pubescentes, internas 3-5 $\mathrm{mm}$ compr., obovadas, denso-tomentosas com tricomas adpressos, ciliadas; pétalas 4, branco-amareladas, 3,1-4 × 1,5-2 mm, obovadas ou largo-elípticas, apêndices das pétalas posteriores com crista emarginada, denso lanosa; lobos nectaríferos posteriores suborbiculares, laterais suborbiculares reduzidos; androginóforo presente; estames 8, 2-3,7 mm compr., velutinos; anteras amarelas, glabras; ovário elipsoide-globoso, 3 -carpelar, glabro; estilete ca. 0,5 mm compr., estigma trilobado. Cápsula septrífraga castanho-avermelhada, crustácea, 2,2-3 × 1,5-1,8 cm, não alada, porção globosa 6-costada, epicarpo e endocarpo glabros; sementes subglobosas, sarcotesta branca recobrindo quase toda a semente; embrião com cotilédones subretos.

Material examinado: BRASIL. Rio de JANEIRo: Engenheiro Paulo de Frontin, Instituto Zoobotânico de Morro Azul, 26-III-2010, bt., A.F. Nunes 48 (RBR).

Material adicional examinado: BRASIL. RIO DE JANEIRO: Itatiaia, 14-VII-1958, fl. masc., H. Monteiro (RBR17112). Piraí, 12-VII-1989, fl. fem., G.V. Somner 573 (RBR). Paraty, 7-VII-1999, fr., L.F.T Menezes (RBR8414).

Distribuição geográfica: ocorre nos Estados de Alagoas, Bahia, Distrito Federal, Espírito Santo, Minas Gerais, Paraíba, Paraná, Pernambuco, Rio de Janeiro, Rio Grande do Norte, Santa Catarina e São Paulo.

Nomes populares: timbó e cipó-timbó-de-santacatarina.

Esta espécie é diferente das outras registradas na área de estudo por apresentar caule cilíndrico, pubescente, estípulas ovado-lanceoladas, folhas biternadas ou pinadas, 11 ou 13-folioladas, folíolos basais 3-foliolulados; pecíolos bicanaliculados ou alados, folíolos com margem inteira e cápsulas castanho-avermelhadas, glabras com a porção globosa 6-costada. Na área de estudo, a espécie floresceu no período de fevereiro a junho.

Paullinia meliifolia Juss., Ann. Mus. Natl. Hist. Nat. 4: 347, pl. 66, f. 2. 1804.

Figura 2s-u

Lianas não lactescentes. Caule subcilíndrico, glabrescente, em seção transversal com apenas um cilindro vascular. Folhas biternadas ou pinadas, $11 \mathrm{ou}$ 13-foliolada, folíolos basais 3-foliolulados; pecíolos canaliculados, alados; estípulas 0,8-1,3×0,5-2,5 mm, falciformes, com escarsos tricomas, ciliadas; folíolos 2-14,5 × 0,8-4cm, cartáceos, elípticos, oblongos, lanceolados ou ovado-romboidais; ápice agudo ou acuminado; base atenuada ou assimétrica; margem denteado-serreada; concolores, face adaxial pubescente apenas na nervura principal, face abaxial pubescente nas nervuras, com domácias pilosas. Tirso racemiforme, 12,5-21,4 cm compr., indumento esbranquiçado, viloso; cincinos 3-6 -floros; pedicelo 2-3,5 mm compr.; brácteas 2-3 $\mathrm{mm}$ compr., linear-subuladas, bracteolas $0.5-1 \mathrm{~mm}$ compr., subuladas. Flores com sépalas 5 , membranáceas, externas 2,2-3,5 mm compr., internas ca. 3,5 mm compr., oblongas, glabras a hirsutas e com tricomas glandulares alaranjados na margem; pétalas 4, brancas, 2,3-4 × 1,1-2 mm, obovadas, apêndices das pétalas posteriores com crista emarginada ou biauriculiforme, vilosa; lobos nectaríferos posteriores ovoides, laterais orbiculares reduzidos; androginóforo presente; estames 8, 2-3,5 mm compr., pilosos no terço basal; anteras amarelas, glabras; ovário trígono-elipsoide ou trígono-globoso, 3-carpelar, pubescente somente nos ângulos; estilete ca. 1,4 mm compr.; estigma trilobado. Cápsula septrífraga avermelhada, subcoriácea, 1,5-1,8 $\times 1,2-1,7 \mathrm{~cm}$, obovóide, trialada, epicarpo glabro, endocarpo denso-lanoso; sementes trígonoobovoides, sarcotesta branca recobrindo metade da semente; embrião com cotilédones subretos.

Material examinado: BRASIL. Rio DE JANEIRo: Engenheiro Paulo de Frontin, Instituto Zoobotânico de Morro Azul, 30-V-2010, fr., A.F. Nunes 66 (RBR). 3-VI-2010, st., A.F. Nunes 70 (RBR).

Material adicional examinado: BRASIL. RIO DE Janeiro: Piraí, 1-VIII-1983. fl. fem., M. Rosa 150 (RBR). Paracambi, 4-XI-2009, fl. masc., G.V. Somner 1492 (RBR).

Distribuição geográfica: ocorre no nordeste da Argentina e na região leste do Paraguai. No Brasil, ocorre nos Estados da Bahia, Minas Gerais, Rio de 
Janeiro, São Paulo, Paraná, Santa Catarina e Rio Grande do Sul.

Nomes populares: timbó-peba, cipó-de-quina, cipótimbó, timbó, timbó-de-folha grande, timbó-vermelho, timbó-de-cipó e tinguí.

Esta espécie distingue-se das outras espécies do gênero ocorrentes na área de estudo por apresentar caule subcilíndrico, glabrescente, estípulas falciformes, ovário pubescente apenas nos ângulos, cápsulas avermelhadas, aladas, com endocarpo denso-lanoso e embrião com cotilédones subretos. Foi coletada com frutos em maio.

Paullinia micrantha Cambess. in A. St.-Hil., Fl. Bras. merid. 1: 373. 1828.

\section{Figura $2 \mathrm{v}-\mathrm{z}$}

Lianas lactescentes. Caule cilíndrico, 5-6-estriado, pubérulo, em seção transversal com apenas um cilindro vascular, pubérulo. Folhas biternadas ou pinadas, 11 ou 13-folioladas, folíolos basais 3-foliolulados; pecíolos canaliculados, marginados ou alados; estípulas $0,5-1 \mathrm{~mm}$, triangulares, pubescentes; folíolos 1-10 $\times 0,5-3 \mathrm{~cm}$, subcoriáceos, subromboidais, elípticos ou ovados; ápice agudo, raro acuminado; base cuneada; margem denteado-serreada; concolores, face adaxial pubérula somente na nervura principal, face abaxial pubérula, com domácias pilosas. Tirso racemiforme, 3,5-10,5 cm compr., indumento amarelado, piloso; cincinos 3-6-floros; pedicelo 1,5-2 mm compr.; brácteas 1-1,5 mm compr., triangulares, bractéolas ca. 0,5 mm compr., triangulares. Flores com sépalas 4, cartáceas, externas ca. $1 \mathrm{~mm}$ compr., suborbidulares, pubérulas, internas ca. $2 \mathrm{~mm}$ compr., obovadas ou emarginada, incano-tomentosas, com tricomas adpressos, ciliadas; pétalas 4, brancas, 2-3 × 1-1,5 mm, obovadas, apêndices das pétalas posteriores com crista erosa ou emarginada; lobos nectaríferos posteriores ovoides, laterais ovoides reduzidos; androginóforo presente; estames 8, 1,5-2,5 mm compr., pubescentes; anteras amarelas, glabras; ovário trígono-elipsoide, 3-carpelar, pubescente somente nos ângulos; estilete ca. $5 \mathrm{~mm}$ compr.; estigma trilobado. Cápsula septrífraga avermelhada, subcoriácea, 1,2-1,7 ×0,9-1 cm, trialadoobovoide, epicarpo glabro, endocarpo tomentoso apenas próximo as margens das valvas; sementes trígono-obovoides, sarcotesta branca recobrindo até dois terços do comprimento da semente; embrião com cotilédone externo curvo e interno biplicado.

Material examinado: BRASIL. Rio de JANEIRo: Engenheiro Paulo de Frontin, Instituto Zoobotânico de Morro Azul, 1-V-2009, fr., G.V. Somner 1324 (RBR).
Material adicional examinado: BRASIL. RIO DE JANEIRO: Vassouras, 2-III-1940, fl. masc., H. MonteiroFilho 192 (RBR). Silva Jardim, 24-I-1995, fl. fem, J.M.A. Braga 1814 (RBR).

Distribuição geográfica: ocorre nos Estados do Alagoas, Bahia, Minas Gerais, Paraíba, Pernambuco, Rio de Janeiro, Rio Grande do Norte, São Paulo e Sergipe.

Esta espécie distingui-se das outras do gênero Paullinia na área de estudo por apresentar folhas biternadas ou pinadas, 11 ou 13-folioladas, folíolos basais 3-foliolulados, estípulas triangulares, ovário trígono-elipsóide, pubescente somente nos ângulos, cápsulas com endocarpo tomentoso apenas próximo as margens das valvas. O período de floração ocorre entre janeiro e março e a frutificação de abril a julho.

Paullinia thalictrifolia Juss., Ann. Mus. Natl. Hist. Nat. 4: 347, pl. 66, f. 1. 1804.

Figura 3a-c

Lianas não lactescentes. Caule não cilíndrico, tomentoso, em seção transversal com apenas um cilindro vascular. Folhas tripinadas; pecíolos marginados; estípulas 0,3-0,5 mm compr., triangulares, pilosas; foliólulos 0,3-2 ×0,3-2,5 cm, subcartáceos, subromboidais, obovados, elípticos; ápice arredondado, levemente agudo ou bilobado no terço superior dos foliólulos; base cuneada ou atenuada; margem denteada, ciliada; discolores, face adaxial verde-escura, às vezes com manchas esbranquiçados no centro dos foliólulos, glabrescente ou pubescente apenas nas nervuras, face abaxial verde opaca, pubescente, com domácias pilosas. Tirso racemiforme, 3,2-9 $\mathrm{cm}$ compr., indumento amarelado, denso-pubescente; cincinos 3-6-floros; pedicelo 1-2 mm compr.; brácteas 1-1,5 mm comp., subuladas, bractéolas ca. $0,5 \mathrm{~mm}$ compr., subuladas. Flores com sépalas 4, coriáceas, externas 1,5-2,5 mm compr., ovadas, tomentosas, internas 2,5-3,5 mm compr., largo-ovadas, tomentosas, com tricomas adpressos, ciliadas; pétalas 4, branco-amareladas, 3-3,5 × 1,5-1,8 mm, oblongo-obovadas, apêndices das pétalas posteriores com crista erosa, denso tomentosa; lobos nectaríferos posteriores suborbiculares, laterais suborbiculares reduzidos; androginóforo presente; estames 8, 2-3,5 mm compr., vilosos; anteras amarelas, glabras; ovário trígono-elipsoide, 3-carpelar, tomentoso; estigma trilobado. Cápsula septrífraga avermelhada, subcoriácea, 1,5-2 ×1-1,6 cm, trialadoobovoide, epicarpo amarelo-tomentoso, depois 


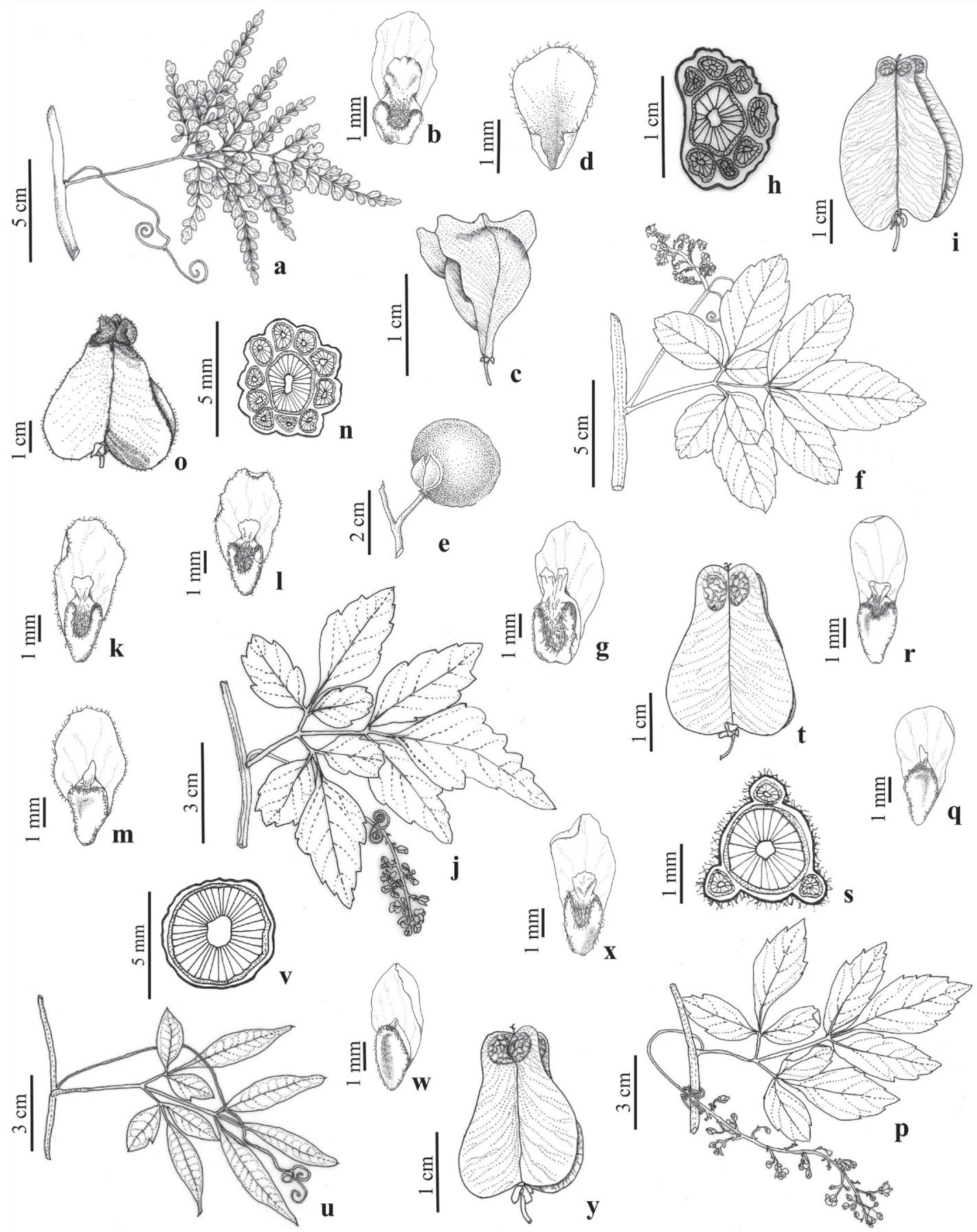

Figura 3. a-c. Paullinia thalictrifolia. a. Folha. b. Pétala posterior. c. Fruto. d-e. Sapindus saponaria. d. Pétala. e. Fruto. f-i. Serjania caracasana. f. Folha e inflorescência. g. Pétala posterior. h. Corte transversal do caule. i. Fruto. j-o. Serjania clematidifolia. j. Folha e inflorescência. k. Pétala posterior emarginada. l. Pétala posterior erosa. m. Pétala lateral. n. Corte transversal do caule. o. Fruto. p-t. Serjania communis. p. Folha e inflorescência. q. Pétala lateral. r. Pétala posterior. s. Corte transversal do caule. t. Fruto. u-y. Serjania gracilis. u. Folha. v. Corte transversal do caule. w. Pétala lateral. x. Pétala posterior. y. Fruto.

Figure 3. a-c. Paullinia thalictrifolia. a. Leaf. b. Posterior petal. c. Fruit. d. Sapindus saponaria. d. Petal. e. Fruit. f-i. Serjania caracasana. f. Leaf and inflorescence. g. Posterior petal. h. Stem transversal section. i. Fruit. j-o. Serjania clematidifolia. j. Leaf and inflorescence. k. Posterior emarginate petal. 1. Posterior erose petal. m. Lateral petal. n. Stem transversal section. o. Fruit. p-t. Serjania communis. p. Leaf and inflorescence. q. Lateral petal. r. Posterior petal. s. Stem transversal section. t. Fruit. u-y. Serjania gracilis. u. Leaf. v. Stem transversal section. w. Lateral petal. x. Posterior petal. y. Fruit. 
glabrescente, endocarpo tomentoso próximo a margem das valvas; sementes trígono-obovoides, sarcotesta branca recobrindo dois terços do comprimento da semente; embrião com cotilédone externo curvo e interno biplicado.

Material examinado: BRASIL. Rio DE JANEIRo: Engenheiro Paulo de Frontin, Instituto Zoobotânico de Morro Azul, 21-V-2010, st., A.F. Nunes 62 (RBR). 21-V-2010, st., A.F. Nunes 63 (RBR).

Material adicional examinado: BRASIL. RIO DE JANEIro: Rio de Janeiro, V-1924, fl.masc., B. Lutz (R15930). Serra dos Órgãos, 25-VII-1973, fl. fem., $P$. Occhioni 5711 (RBR). Espírito Santo, 17-VII-1985, fr., A.B. Fontana (CEPEC66129).

Distribuição geográfica: ocorre nos Estados do Mato Grosso, Minas Gerais, Espírito Santo, Rio de Janeiro e São Paulo.

Nomes populares: camaihua, camaihua-cipó, camihuacipó, quanacai-cipó e jacatupé.

Esta espécie difere das demais espécies do gênero Paullinia registradas no IZMA por apresentar caule estriado, tomentoso, folhas tripinadas, pecíolos marginados e cápsulas trialadas, com epicarpo amarelo-tomentoso e endocarpo tomentoso próximo a margem das valvas. Uma característica marcante observada durante as expedições na área de estudo foi a formação de pequenas moitas resultantes de intenso crescimento vegetativo. Até ser registrada na área de estudo, havia 80 anos que esta espécie não era coletada no Estado do Rio de Janeiro. Esta espécie não foi coletada com flores ou frutos na área de estudo. Entretanto, de acordo com registros nos herbários consultados, houve registro de floração de P. thalictrifolia para outras áreas no Estado do Rio de Janeiro, entre os meses de fevereiro e maio.

Sapindus saponaria L., Sp. Pl. 1: 367. 1753. Figura 3d-e

Árvore ca. $6 \mathrm{~m}$ alt. Ramos cilíndricos, pubescentes, depois glabros. Folhas 6-12 folioladas, com 9-21 cm compr. e folíolo distal rudimentar, em forma de apículo; pecíolo alado; folíolos 2-11 × 0,9-3,7 cm, cartáceos, assimétricos, estreito-elípticos a ovado-lanceolados; ápice obtuso, acuminado, ou falciforme; base assimétrica ou cuneada; margem inteira; discolores, face adaxial verde-clara, com raros tricomas dispersos, face abaxial verde-amarelada, pubérula ou pubescente, com domácias ausentes. Tirso paniculiforme, ca. 16,5 cm compr., indumento castanho-amarelado, denso-pubérulo; pedicelo ca. $1 \mathrm{~mm}$ compr.; brácteas ca. $2 \mathrm{~mm}$ compr., triangulares, bractéolas ca. 1 mm compr., lanceoladas. Flores com sépalas 5, 1-2 × 1-2 mm, membranáceas, ovadas ou obovadas, glabras, ciliadas; pétalas 5 , branco-amareladas, 2-3,5 $\times 1,5 \mathrm{~mm}$, obovadas, apêndice petaloide bipartido, fendido medialmente até a base da pétala, atingindo o terço basal da pétala, tomentoso; disco nectarífero anelar, crenado; androginóforo ausente; estames 8, 1,8-3 mm compr., vilosos no terço basal; anteras amarelas, glabras; ovário trilobado-obovoide, 3-carpelar, glabro; estilete ca. 1,5 mm compr.; estigma conato, trilobado. Mericarpos baciformes, com 1-2 cocos rudimentares, amarelados, quando maduros castanho-escuros ou pretos, mesocarpo gelatinoso e resinoso, ca. 1,7 cm diâm., globosos, epicarpo glabro, endocarpo transparente; sementes subglobosas; embrião com cotilédones subretos.

Material examinado: BRASIL. Rio DE JANEIRo: Engenheiro Paulo de Frontin, Instituto Zoobotânico de Morro Azul, 1-V-2009, st., A.F. Nunes 109 (RBR).

Material adicional examinado: BRASIL. MINAS Gerais: Santana de Pirapama, 13-VII-1970, fr., P.L. Krieger 8815 (RBR). São Paulo: São Paulo, 14-V-1984, fl. fem. e masc., M. Bittar (RBR29411).

Distribuição geográfica: ocorre desde o sul dos Estados Unidos da América até o norte da Argentina. No Brasil, há registros em quase todo território brasileiro, com exceção do Amapá, Espírito Santo, Piauí, Maranhão, Rio Grande do Sul, Rondônia, Roraima e Santa Catarina.

Nomes populares: saboneteira, sabonete-de-macaco, sabonete-de-soldado, assobio-de-macaco, sabão-demico, saboeiro.

É possível distinguir esta espécie das outras registradas para a área de estudo porque ela apresenta folhas com pecíolo alado, folíolos com margem inteira, com domácias ausentes, disco nectarífero anelar, crenado, mericarpos baciformes com 1-2 cocos rudimentares, amarelados, quando maduros castanhoescuros ou pretos, globosos, com mesocarpo gelatinoso e resinoso, endocarpo transparente, subcartilaginoso. Não foram coletados materiais férteis desta espécie na área de estudo. Porém, de acordo com registros nos herbários consultados, esta espécie floresce de maio a junho e frutifica de agosto a dezembro.

Serjania caracasana (Jacq.) Willd., Sp. pl. 2(1): 465. 1799.

Figura 3f-i

Lianas lactescentes. Caule subcilíndrico, 7-8-costado, glabro, em seção transversal com um 
cilindro central maior e 7-8 cilindros periféricos menores, glabro. Folhas biternadas ou pinadas (3) 5-folioladas; pecíolos canaliculados ou marginados; estípulas 1-2 mm, triangulares, pilosas; folíolos 2,1-11 $\times 1,5-5,8 \mathrm{~cm}$, cartáceos, elípticos, oblongos ou ovados; ápice obtuso, agudo ou acuminado; base decurrente, obtusa ou assimétrica; margem denteado-serreada; discolores, face adaxial verde-escura, lustrosa, glabra ou pubérula na nervura principal, face abaxial verdeclara, glabra ou pubescente, com domácias pilosas. Tirso racemiforme, 9,2-13,2 cm compr., indumento esbranquiçado, pubérulo; cincinos 4-6-floros; pedicelo ca. 3,5 mm compr.; brácteas 1-1,5 mm compr., triangulares, bractéolas 0,5-1 mm compr., triangulares. Flores com sépalas 5, cartáceas, 4-5 × 1,5-2 mm, ovadas ou oblongas, externas glabras, internas pubescentes, ciliadas; pétalas 4 , branco-amareladas, 5-6 × 1,5-2 mm, obovóides ou oblongas, apêndice petaloide das pétalas posteriores com crista bipartida, viloso; lobos nectaríferos posteriores ovoides, laterais subelipsoides ou orbiculares reduzidos; androginóforo presente; estames 8, 3,2-5,5 mm compr., glabros ou pubescentes; anteras amarelas, glabras; ovário trígono-obovoide, 3-carpelar, pubérulo somente nos ângulos e com tricomas glandulares dispersos; estilete ca. 1,2 mm compr.; estigma trilobado. Mericarpos samaroides castanhos, cartáceos, 1,7-2,5 × 2,8-3,2 cm, ovado-cordados, porção seminífera do mericarpo obovada, inflada, às vezes com crista dorsal estreita, epicarpo e endocarpo glabros; sementes subglobosas; embrião com cotilédone externo curvo e interno biplicado.

Material examinado: BRASIL. Rio DE JANEIRo: Engenheiro Paulo de Frontin, 12-VII-2009, fl. A.F. Nunes 23 (RBR). 6-VIII-2010, fr., A.F. Nunes 89 (RBR).

Material adicional examinado: BRASIL. RIO DE Janeiro: Niterói, 15-VIII-2009, fr., G.V. Somner 141 (RBR). Mangaratiba, 14-VII-1983, fr., L.B. Pace 7 (RBR). 6-VII-1993, fl. masc., G.V. Somner 762 (RBR).

Distribuição geográfica: espécie com distribuição Neotropical. No Brasil, há registros para quase todo o território, com exceção de Alagoas, Ceará, Maranhão, Rio Grande do Norte, Rio Grande do Sul, Santa Catarina, Sergipe e Tocantins.

Nomes populares: cipó-d'água e tingui-da-mata.

Distingue-se das outras espécies do gênero encontradas na área de estudo por apresentar caule em seção transversal com um cilindro central maior e 7-8 periféricos menores ao redor do central, folhas biternadas, pinadas 5 -folioladas ou raramente trifoliolada, mericarpos samaroides, com a porção seminífera obovada e inflada, epicarpo e endocarpo glabros. Foi coletada com flores em julho e frutos em agosto.

Serjania clematidifolia Cambess. in A. St.-Hil., Fl. Bras. Merid. 1: 361. 1828.

Figura 3j-o

Lianas lactescentes. Caule 9-10-sulcado, sulcos conspícuos, tomentoso, em seção transversal com um cilindro vascular central maior e 8-10 cilindros periféricos menores. Folhas biternadas; pecíolos canaliculados; estípulas 1-2 mm, elípticas, densotomentosas; folíolos, 1,3-5,8 × 0,8-4,5 cm, cartáceos, romboidais, ovados ou elípticos; ápice agudo, acuminado ou retuso; base cuneada ou atenuada; margem denteado-serreada; discolores, face adaxial verde-escura, pubescente na nervura principal, face abaxial com indumento branco-amarelado, denso-pubescente, com domácias pilosas. Tirso racemiforme, 6,2-14,5 $\mathrm{cm}$, indumento brancoamarelado, tomentoso; cincinos 4-6-floros; pedicelo 2,5-3 mm compr.; brácteas 3-3,5 mm compr., elípticas, bractéolas 1,5-2,5 mm compr., subuladas. Flores com sépalas 5, cartáceas, externas 3-5 mm compr., oblongas, denso-tomentosas, internas 5-5,5 mm compr., obovadas, denso-tomentosas, ciliadas; pétalas 4 , brancas, ca. $4 \mathrm{~mm}$ compr., obovadas, apêndice petaloide das pétalas posteriores com crista emarginada ou bipartida, viloso; lobos nectaríferos posteriores orbiculares, laterais ovoides, reduzidos; androginóforo presente; estames 8, 3-4 mm compr., seríceo-tomentosos; anteras amarelas, glabras; ovário trígono-obovóide, 3-carpelar, denso-pubescente; estilete ca. $1 \mathrm{~mm}$ compr.; estigma trífido. Mericarpos samaroides, castanhos, catáceos, 2,4-2,7 × 1,8-2,2 cm, ovado-cordados, porção seminífera do mericarpo subglobosa, côncava na porção lateral de cada mericarpo, crista dorsal ausente, epicarpo pubescente, endocarpo densamente lanoso; sementes subglobosas; embrião com cotilédone externo curvo e interno biplicado.

Material examinado: BRASIL. Rio de JANEIRo: Engenheiro Paulo de Frontin, Instituto Zoobotânico de Morro Azul, 15-VII-2010, fl.masc., A.F. Nunes 85 (RBR). 
Material adicional examinado: BRASIL. RIo DE JANEIRO: Saquarema, 26-VIII-1991, fr., G.V. Somner 653 (RBR). Mangaratiba, 16-VI-1994, fl. fem., G.V. Somner 789 (RBR). Niterói, 18-VII-1990, fl. masc., S.A. Rego 1031 (RBR).

Distribuição geográfica: ocorre nos Estados da Amazonas, Amapá, Bahia, Distrito Federal, Pará, Paraná, Espírito Santo, Goiás, Mato Grosso do Sul, Minas Gerais, Rio de Janeiro e Tocantins.

Serjania clematidifolia é diferente das outras espécies registradas no IZMA porque apresenta caule 9-10-sulcado, com sulcos conspícuos, em seção transversal com um cilindro vascular central maior e 8-10 cilindros periféricos menores ao redor do central, mericarpos samaroides pubescentes com porção seminífera subglobosa, côncava na porção lateral de cada mericarpo, com epicarpo pubescente e endocarpo densamente lanoso. Há registros de floração para esta espécie entre os meses de junho e agosto e de frutificação entre setembro e outubro.

Serjania communis Cambess. in A. St.-Hil., Fl. Bras. merid. 1: 362. 1828.

Figura 3p-t

Lianas não lactescentes. Caule triangular. 3-costado, tomentoso, em seção transversal com um cilindro central e três cilindros periféricos menores, equidistantes. Folhas biternadas; pecíolos, canaliculados; estípulas 1-3,5 mm, ovadas, tomentosas; folíolos 2-11 x 0,5-5cm, cartáceos, ovados, elípticos ou romboidais; ápice apiculado; base cuneada, atenuada ou assimétrica; margem denteado-serreada; discolores, face abaxial verde-pálida, pubescente a pubérula, face adaxial verde-escura, glabra e pubescente, com domácias ausentes. Tirso racemiforme, 3,7-22,5 cm compr., pubescente; cincinos 4-5-floros; pedicelo 2-2,5 mm compr.; brácteas 1,2-1,5 mm compr., subuladas, bractéolas ca. $1 \mathrm{~mm}$ compr., subuladas. Flores com sépalas 4, subcoriáceas, externa 1,5-3 $\mathrm{mm}$ compr., ovadas, tomentosas, internas 4-6 mm compr., oblongas ou ovadas; pétalas 4 , esverdeadas, 3,5-4 × 2,5-3 mm, obovadas, apêndice petaloide das pétalas posteriores com crista erosa ou emarginada; lobos nectaríferos posteriores ovóides, laterais ovoides reduzidos; androginóforo presente; estames 8, 2,5-4,5 mm compr., pubescentes; anteras amarelas, glabras; ovário trígono-obovóide, 3-carpelar, denso pubescente; estilete ca. $1 \mathrm{~mm}$ compr.; estigma trilobado. Mericarpos samaroides, castanho-claros, cartáceos, 2,2-2,5 × 1,8-2 cm, subretangulares ou subcordados, porção seminífera do mericarpo achatada lateralmente, com crista dorsal 2-2,5 mm larg., epicarpo glabro ou pubérulo, endocarpo piloso ou viloso; sementes lenticulares; embrião com cotilédones subretos.

Material examinado: BRASIL. Rio DE JANEIRo: Engenheiro Paulo de Frontin, Instituto Zoobotânico de Morro Azul, 1-V-2009, bt., G.V. Somner 1325 (RBR). 3-VI-2010, fl. masc., A.F. Nunes 69 (RBR).

Material adicional examinado: BRASIL. BAHIA: Una, 11-IX-1974, fl. masc., T.S. Santos 2800 (RBR). Rio DE JANEIRO: Niterói, 15-VIII-2009, fr., G.V. Somner 1409 (RBR).

Distribuição geográfica: distribui-se desde a Venezuela até a Bolívia. No Brasil, ocorre nos Estados do Acre, Amazonas, Bahia, Distrito Federal, Espírito Santo, Minas Gerais, Paraná, Rio de Janeiro, Rio Grande do Sul, Rondônia, Santa Catarina e São Paulo.

Nome popular: cipó timbó.

Esta espécie é diferente das demais do gênero no IZMA por apresentar caule triangular, em seção transversal com um cilindro central e três cilindros periféricos menores equidistantes e mericarpos samaroides glabros ou pubérulos, com a porção seminífera achatada lateralmente. Foi registrada com flores entre maio e junho.

Serjania corrugata Radlk., Consp. sect. sp. Serjan. 131. 1874.

Figura 4 f-j

Lianas não lactescentes. Caule subcilíndrico, 5-costado, com tricomas glandulares alaranjados, dispersos, em seção transversal com um cilindro vascular central muito reduzido e cinco cilindros vasculares radialmente dispostos, com tricomas glandulares alaranjados dispersos. Folhas biternadas; pecíolos bicanaliculados; estípulas 0,7-1 mm, triangulares ou lanceoladas, tricomas setosos dispersos e glandulares na margem; folíolos 1,8-8,9 × 1,2-3,5 cm, cartáceos, estreito-ovados, ovados, lanceolados; ápice acuminado; base cuneada, atenuada ou assimétricas; margem inteira ou 1-2-denteada; concolores, face adaxial pubérula nas nervuras, face abaxial pubescente na nervura principal, com domácias pilosas. Tirso racemiforme, 4,5-7,5 cm compr., indumento brancoamarelado, pubescente e com tricomas glandulares alaranjados; cincino 2-4-floros; brácteas $0,7-1 \mathrm{~mm}$ compr., subuladas, bractéolas ca. $0,5 \mathrm{~mm}$ compr., subuladas; Flores com sépalas 5, membranáceas, externas ca. 2,5 mm compr., ovadas, com tricomas 

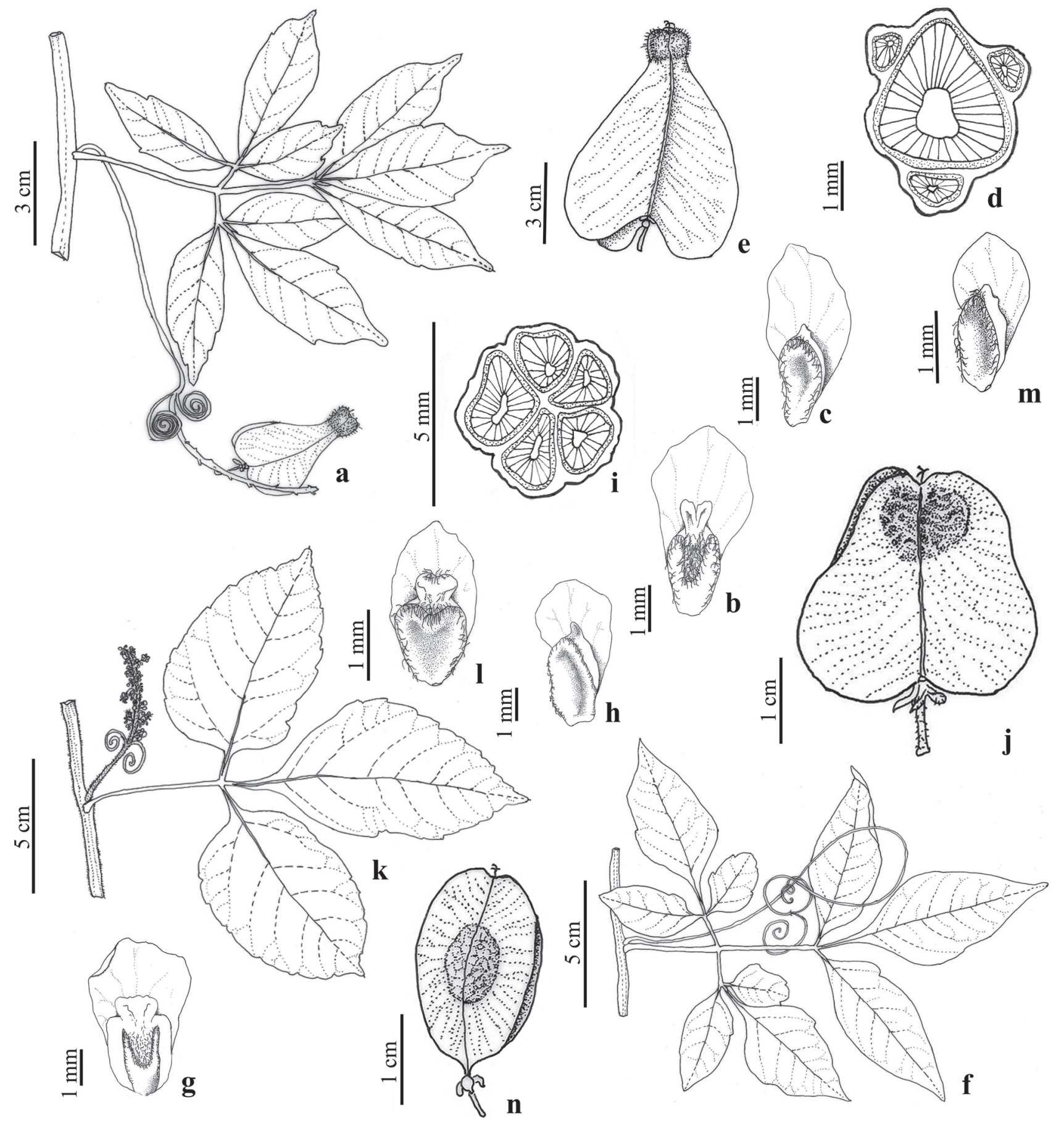

Figura 4. a-e. Serjania lethalis. a. Folha e infrutescência. b. Pétala posterior. c. Pétala lateral. d. Corte transversal do caule. e. Fruto. f-j. Serjania corrugata. f. Folha. g. pétala posterior. h. Pétala lateral. i. Corte transversal do caule. j. Fruto. k-n. Urvillea rufescens. k. Folha e inflorescência. 1. Pétala posterior. m. Pétala lateral. n. fruto.

Figure 4. a-e. Serjania lethalis. a. Leaf and infructescence. b. Posterior petal. c. Lateral petal. d. Stem transversal section. e. Fruit. f-j. Serjania corrugata. f. Leaf. g. Posterior petal. h. Lateral petal. i. Stem transversal section. j. Fruit. k-n. Urvillea rufescens. k. Leaf and inflorescence. 1. Posterior petal. m. Lateral petal. n. Fruit. 
glandulares, internas 3-3,5 mm compr., elípticas, face externa denso-pubescentes; pétalas 4 , brancas, 4-5 × 2-2,5 mm, obovadas, apêndice petaloide das pétalas posteriores com crista erosa; lobos nectaríferos posteriores ovoides, laterais ovoides, reduzidos; androginóforo presente; estames 8, 2-4 mm compr., pubescentes; anteras amarelas, glabras; ovário trígono-obovóide, 3-carpelar, pubérulo somente nos ângulos, com tricomas glandulares alaranjados dispersos; estilete ca. $1 \mathrm{~mm}$ compr., estigma trilobado. Mericarpos samaroides, castanho-escuros, cartáceos, 3-3,4 × 3,2-3,3 cm, ovado-cordados, porção seminífera do mericarpo pouco inflada, com crista dorsal 2,5-3 mm larg., epicarpo pubérulo na porção seminífera e margem das alas, endocarpo lanoso; sementes obovadas; embrião com cotilédone externo curvo e interno biplicado.

Material examinado: BRASIL. Rio de JANEIRo: Engenheiro Paulo de Frontin, Instituto Zoobotânico de Morro Azul, 15-VII-2010, st., A.F. Nunes 76 (RBR).

Material adicional examinado: BRASIL. MINAS GeraIs: Buenópolis, 15-III-2007, fl masc., L. Pangaio 940 (RBR). Santa Bárbara, 26-IX-2002, fl fem., J.R. Stehmann 3127 (RBR). 26-IX-2002, fr., J.R. Stehmann 3101 (RBR). Rio DE JANEIRO: Rio de Janeiro, restinga de Jacarepaguá, Pedra de Itauna, lado oeste, 25-V-1973, fr., D.S.D. Araujo 191 (RB).

Distribuição geográfica: ocorre nos Estados da Bahia, Espírito Santo, Minas Gerais, Rio de Janeiro, Rio Grande do Norte e São Paulo.

Diferente das outras espécies presentes no IZMA, Serjania corrugata apresenta caule em seção transversal com um cilindro vascular central muito reduzido e 5 cilindros vasculares dispostos radialmente e mericarpos samaroides pubérulos, com porção seminífera pouco inflada e com crista dorsal presente. Não foi registrada com flores nem frutos na área de estudo.

Serjania gracilis Radlk., Consp. sect. sp. Serjan. 134. 1874.

Figura 3u-y

Lianas não lactescentes. Caule 6-costado, costas inconspícuas, com tricomas setosos dispersos, em seção transversal com apenas um cilindro vascular. Folhas biternadas; pecíolos bicanaliculados; estípulas 0,5-0,7 mm, triangulares ou ovadas, raros tricomas setosos dispersos; folíolos 1,5-9 × 0,5-2 cm, cartáceos, oblongos ou ovadolanceolados; ápice acuminado; base cuneada ou atenuada; margem inteira ou às vezes 1-2-denteada; concolores, face adaxial glabra, face abaxial com tricomas glandulares, com domácias ausentes. Tirso racemiforme, $6,5-11,5 \mathrm{~cm}$ compr., indumento esbranquiçado, pubescente; cincinos 4-6 floros; pedicelo 3-3,5 cm compr.; brácteas ca. 1 mm compr., subuladas, bractéolas ca. $0,5 \mathrm{~mm}$ compr., subuladas. Flores com sépalas 5, 2,5-3 mm compr., cartáceas, ovadas, externas glabras ou pubescentes, internas velutinas; pétalas 4 , branco-amareladas, 4-4,5 $\times$ 1,5-2 mm, obovadas, apêndice petaloide das pétalas posteriores com crista inteira ou erosa; lobos nectaríferos posteriores ovoides, laterais elipsoides; androginóforo presente; estames 8, 2,5-4 mm compr., pubérulos; anteras amarelas, pilosas; ovário trígono-obovóide, 3-carpelar, piloso somente nos ângulos, estilete ca. $1 \mathrm{~mm}$ compr., estigma trífido. Mericarpos samaroides, castanho-claros, cartáceos, 1,7-2,8 × 1,2-2 cm, ovado-cordados, porção seminífera do mericarpo inflado, crista dorsal ca. $1,5 \mathrm{~mm}$ larg., epicarpo glabro, endocarpo pubérulo; sementes trígono-obovóides, achatadas lateralmente, 3-3,5 × 2,5-3 mm, pubérulas; embrião com cotilédone externo curvo e interno biplicado.

Material examinado: BRASIL. Rio DE JANEIRO: Engenheiro Paulo de Frontin, Instituto Zoobotânico de Morro Azul, 15-VII-2010, st., A.F. Nunes 78 (RBR).

Material adicional examinado: BRASIL. MINAS Gerais: Ouro Preto, 19-VIII-1971, fr., U. Confúcio 10737 (RBR). BR 135, Km 404, 26-V-1971, fl. masc. e fem., P.L. Krieger 10591 (RBR). Rio DE JANEIRO: Itatiaia, 20-IV-1959, fl. masc., Ags (R2806).

Distribuição geográfica: No Brasil há registros nos Estados da Bahia, Minas Gerais, Rio de Janeiro, São Paulo, Paraná e Santa Catarina.

Esta espécie diferencia-se das outras do gênero Serjania presentes na área de estudo por apresentar o caule em seção transversal com apenas um cilindro vascular, folíolos com margem inteira ou às vezes 1-2 denteada, face adaxial glabra e face abaxial com tricomas glandulares, mericarpos samaroides com porção seminífera inflada e crista dorsal presente, epicarpo glabro e endocarpo pubérulo. Assim como Paullinia thalictrifolia, esta espécie apresentava um lapso temporal de coleta no Rio de Janeiro, estando há mais de 40 anos sem ser amostrada. Esta espécie, assim como $S$. corrugata não foi registrada em período de floração e frutificação na área de estudo. Porém, de acordo com registros dos herbários consultados, esta espécie foi coletada com flores em outubro e de abril a julho, e com frutos em setembro e de abril a maio.

Serjania lethalis A. St.-Hil., Hist. P1. Remarq. Bresil 1: 235.1824.

Figura 4a-e 
Lianas não lactescentes. Caule subcilíndrico ou 3-costado, glabro, em seção transversal composto por um cilindro vascular central e 3-4 (5) cilindros vasculares periféricos, quando mais de 3 , dispostos aos pares. Folhas biternadas; pecíolos canaliculados; estípulas ca. $1 \mathrm{~mm}$, triangulares, glabrescentes; folíolos 3-15 × 1,5-5,5 cm, cartáceos, lanceoladoelípticos, elípticos, oblongos ou levemente obovados; ápice acuminado ou cuspidado; base cuneada ou assimétrica; margem inteira ou com 1-3 dentes apicais; concolores, face adaxial glabra, face abaxial pubérula na nervura principal, com domácias pilosas. Tirso racemiforme, 7-26 cm compr., indumento brancoamarelado, denso-pubescente; cincinos 5-6-floros; pedicelo 1,2-1,7 mm compr.; brácteas 1,5-2 mm compr., subuladas, bractéolas ca. $1 \mathrm{~mm}$ compr., subuladas. Flores com sépalas 5, cartáceas, externas ca. $1,5 \mathrm{~mm}$ compr., obovadas, pubescentes, internas 2,5-3 mm compr., obovadas ou oblongas, tomentosas; pétalas 4 , brancas, $2-5 \mathrm{~mm}$ compr., obovadas, apêndice petaloide das pétalas posteriores com crista bipartida; lobos nectaríferos posteriores ovoides, laterais elipsoides; androginóforo presente; estames 8, 1,7-3,5 mm compr., pubérulos; anteras amarelas, glabras; ovário trígono-obovóide, 3-carpelar, densotomentoso; estilete ca. 0,7 $\mathrm{mm}$ compr.; estigma trífido. Mericarpos samaroides, castanho-amarelados, cartáceos, 1,2-3,5 × 2-2,8 cm, ovado-cordados, porção seminífera do mericarpo globosa, tomentosa, crista dorsal ausente, alas pubérulas ou glabras, endocarpo pubérulo ou glabro; sementes subglobosas; embrião com cotilédone externo curvo e interno biplicado.

Material examinado: BRASIL. Rio de JANEIRo: Engenheiro Paulo de Frontin, Instituto Zoobotânico de Morro Azul, 20-XII-2008, fr., G.V. Somner 1262 (RBR).

Material adicional examinado: BRASIL. RIO DE JANEIRO: Piraí, 25-IX-1984, fl. masc. e fl. fem., M. Rosa 203 (RBR). São PAULo: Mogi-Guaçú, 25-IX-1991, fr., S. Romaniuc Neto 1252 (RBR).

Distribuição geográfica: ocorre na Bolívia, Paraguai, Peru e no Brasil, há registro para quase todo o território nacional, com exceção dos Estados do Pará, Rio Grande do Sul, Rondônia, Roraima e Sergipe.

Nomes populares: cipó timbó, timbó, mata-fome.

Serjania lethalis difere das espécies mesmo do gênero registradas na área de estudo pela presença de caule subcilíndrico ou 3-costado, glabro, em seção transversal com um cilindro vascular central maior e 3-4 (5) cilindros periféricos vasculares, quando mais de 3 dispostos aos pares, folíolos com margem inteira ou 1-3 denteada no ápice, mericarpos samaroides com porção seminífera globosa tomentosa, sem crista dorsal. A floração foi registrada nos meses de setembro e outubro e a frutificação entre novembro e dezembro.

Urvillea rufescens Cambess. in A. St.-Hil., Fl. Bras. Merid. 1: 354. 1828.

Figura 4k-n

Lianas não lactescentes. Caule trilobado, com lobos conspícuos, pubescente, em seção transversal com apenas um cilindro vascular. Folhas trifolioladas; pecíolos bicanaliculados; estípulas $0,6-1,2 \mathrm{~mm}$, triangulares, pubescentes; folíolos 2-9,5 × 1,5-5,2 cm, subcoriáceos, ovados ou romboidais; ápice obtuso ou mucronado; base atenuada; margem crenadodenteada; discolores, face adaxial verde-escura, pubérula, face abaxial castanho-esverdeada, pubérula, com domácias ausentes. Tirso espiciforme, 1,7-6,8 cm compr., indumento castanho-amarelado, pubescente e com tricomas glandulares; cincinos 6-9-floros; pedicelo 0,7-1 mm compr.; brácteas ca. 0,5 mm compr., triangulares, bractéolas $0,1-0,2 \mathrm{~mm}$ compr., triangulares. Flores com sépalas 5, 1,5-2 mm compr., cartáceas, externas ovadas, internas obovadas, margem com tricomas glandulares alaranjados; pétalas 4 , brancas, $1-1,5 \times 0,6-1 \mathrm{~mm}$, obovadas, apêndice petaloide das pétalas posteriores com crista emarginada; lobos nectaríferos posteriores ovoides, laterais elipsoides; androginóforo presente; estames 8, 1,2-3,7 mm compr., pubérulos; anteras purpúreas, glabras; ovário trígono-elipsóide, 3 -carpelar, pubescente; estilete ca. 0,3 mm compr.; estigma trilobado. Cápsula septífraga, castanhoclara, subcartácea, 1,5-2,5 × 1-1,5 cm, elipsóide ou obovóide, trialada, porção central inflada, crista dorsal ausente, epicarpo pubérulo ou pubescente, endocarpo pubérulo; sementes ovoides; embrião, com cotilédone externo curvo e interno biplicado.

Material examinado: BRASIL. RIO DE JANEIRO: Engenheiro Paulo de Frontin, Instituto Zoobotânico de Morro Azul, 15-VII-2010, st., A.F. Nunes 82 (RBR). 6-VIII-2010, fl. masc., A.F. Nunes 88 (RBR).

Material adicional examinado: BRASIL. EsPíRITo SAnto: Linhares, 22-VIII-1991, fl. masc., V. de Souza 164 (RBR). Rio DE JANEIRO: Rio das Ostras, 24-IX-2008, fr., M.F. Faria 137 (RBR); Saquarema, 13-VIII-1992, fl. fem., G.V. Somner 752 (RBR).

Distribuição geográfica: ocorre nos Estados da Bahia, Espírito Santo, Minas Gerais, Pernambuco, Rio de Janeiro e São Paulo. 
Diferente das outras espécies de lianas da família registradas para o IZMA por apresentar caule trilobado, com lobos conspícuos, em seção transversal com apenas um cilindro vascular, folhas trifolioladas, anteras purpúreas e cápsulas castanhoclaras, trialadas, subcartáceas e infladas na porção central. Foi registrada com flores em agosto.

\section{Agradecimentos}

Agradecemos ao Instituto Zoobotânico de Morro Azul, especialmente ao Hélio Freitas e a Cecília Monteiro, por todo apoio logístico e pela permissão para o desenvolvimento deste trabalho na área. À amiga e professora Marilena Conde e ao amigo André Luiz Gomes de Carvalho, pelas preciosas sugestões ao longo do desenvolvimento deste trabalho e na correção do manuscrito. Ao revisor pelas excelentes sugestões e correções que levaram ao aprimoramento deste manuscrito. Ao Herbário RBR do Departamento de Botânica da Universidade Federal Rural do Rio de Janeiro, pela estrutura oferecida para o tratamento botânico das plantas coletadas e disponibilização de equipamentos para a confecção das ilustrações. À FAPERJ, pela bolsa de iniciação científica concedida à primeira Autora (E-26/100.544/2010).

\section{Literatura citada}

Acevedo-Rodríguez, P., Van Welzen, P.C., Adema, F. \& Van Der Ham, R.W.J.M. 2011. Sapindaceae. In: K. Kubitzky (ed.). Flowering Plants, Eudicots: Sapindales, Curcubitales, Myrtaceae, The Families and Genera of vascular plants. Springer-Verlag, Belin Heidelberg, pp. 371-422.

Barros, A.A.M. 2008. Análise florística e estrutural do Parque Estadual da Serra da Tiririca, Niterói e Maricá, RJ, Brasil. Tese de Doutorado, Instituto de Pesquisas Jardim Botânico do Rio de Janeiro, Escola Nacional de Botânica Tropical, Rio de Janeiro.

Barroso, G.M., Morim, M.P., Peixoto, A.L. \& Ichaso, C.L.F. 1999. Frutos e sementes: morfologia aplicada à sistemática de dicotiledôneas. 2 ed. Editora UFV, Viçosa, pp. 287-294.

Bastos, J. \& Napoleão, P (orgs.). 2011. O estado do ambiente: indicadores ambientais do Rio de Janeiro. Secretaria de Estado do Ambiente, INEA, Rio de Janeiro.

Buerki, S, Lowry Ii, P.P., Alvarez, N., Razafimandimbison, S. G., Küpfer, P. \& Callmander, M. W. 2010. Phylogeny and circumscription of Sapindaceae revisited: Molecular sequence data, morphology and biogeography support recognition of a new family, Xanthoceraceae. Plant Ecology and Evolution, 143: 148-159.
Dan, M.L., Braga, J.M.A. \& Nascimento, M.T. 2010. Estrutura da comunidade arbórea de fragmentos de floresta estacional semidecidual na bacia hidrográfica do rio São Domingos, Rio de Janeiro, Brasil. Rodriguésia, 61: 749-766.

Faria, M.S. 2009. Trepadeiras da família Sapindaceae nas restingas do estado do Rio de Janeiro, Brasil. Dissertação de Mestrado, Instituto de Pesquisa Jardim Botânico, Escola Nacional de Botânica Tropical, Rio de Janeiro.

Flora do Brasil 2020 em construção. 2016. Jardim Botânico do Rio de Janeiro. Disponível em http:// floradobrasil.jbrj.gov.br/ (acesso em 09-VII-2016).

Fundação SOS Mata Atlântica \& Conservação Internacional. 2010. Corredores de biodiversidade da Mata Atlântica. Disponível em http://corredores.org. $\mathrm{br} /$ ?area $=$ ma (acesso em 11-VIII-2010).

Gadek, P.A., Fernando, E.S., Quinn, C.J., Hoot, S.B., Terrazas, T., Sheahan, M.C. \& Chase, M.W. 1996. Sapindales: Molecular delimitation and infraordinal groups. American Journal of Botany 83: 802-811.

Guarim-Neto, G., Santana, S.R. \& Silva, J.V.B. 2000. Notas etnobotânicas de espécies de Sapindaceae Juss. Acta Botanica Brasilica 14: 327-334.

Harrington, M.G., Edwards, K.J., Johnson, S.A., Chase, M.W. \& Gadek, P.A. 2005. Phylogenetic inference in Sapindaceae sensu lato using plastid matK and rbcL DNA sequences. Systematic Botany 30: 366-382.

Hickey, L.J. 1974. Classificacion de la arquitetura de las hojas de dicotiledoneas. Boletín de la sociedad argentina de botánica, 16: 1-26.

Hickey, M. \& King, C. 2000. Illustrated glossary of botanical terms. Cambridge University Press, Cambridge.

IPNI - The International Plant Names Index. 2016. Disponível em http://www.ipni.org (acesso em 7-VII-2016).

Köppen, W. 1948. Climatologia: Com um estudio de los climas de la tierra. Fundo de Cultura Económica, México.

Kurtz, B.C., Sá, C.F.C. \& Silva, D.O. 2009. Fitossociologia do componente arbustivo-arbóreo de Florestas Semidecíduas Costeiras da região de Emerenças, Área de Proteção Ambiental do Pau Brasil, Armação dos Búzios, Rio de Janeiro, Brasil. Rodriguésia, 60: 129-146.

Lima, H.C., Lima, M.P.M., Vaz, A.M.S.F. \& Pessoa, S.V.A. 1997. Trepadeiras da Reserva Ecológica de Macaé de Cima. In: H.C. Lima \& R.R. Guedes-Bruni (eds). Serra de Macaé de Cima: Diversidade Florística e Composição em Mata Atlântica. Instituto de Pesquisas Jardim Botânico do Rio de Janeiro, Rio de Janeiro, pp. $75-88$. 
Lima, H.C., Morim, M.P., Guedes-Bruni, R.R., Sylvestre, L.S., Pessoa, S.V.A., Silva-Neto, S.V.A., Quinet, A., Guimarães, E.F. \& Mansano, V. 2008. Reserva Biológica de Poço das Antas. Lista de espécies vasculares. Disponível em http://graziela.jbrj.gov.br/ pesquisa/pma/macaedecima/checklist/Lista_Plantas_ vasculares_apresentação.htm (acesso em 20-VIII-2010).

Luz, C.F.P., Thomé, M.L. Barth, O.M. 2007. Recursos tróficos de Apis melífera L. (Hymenoptera, Apidae) na região de Morro Azul do Tinguá, estado do Rio de Janeiro. Revista Brasileira de Botânica 30: 29-36.

Morellato, L.P.C. \& Haddad, C.F.B. 2000. Introduction: The Brazilian Atlantic Forest. Biotropica 32: 786-792.

Mori, S.A., Silva, L.A., Lisboa, G. \& Coradin, L. 1985. Manual de manejo do herbário fanerogâmico. CEPLAC, Itabuna.

Myers, N., Mittermeier, R.A., Mittermeier, C.G., Fonseca, G.A.B. \& Kent, J. 2000. Biodiversity hotspots for conservation priorities. Nature 403: 853-858.

Oliveira, M.A., Grillo, A.S. \& Tabarelli, M. 2004. Forest edge in the Brazilian Atlantic forest: drastic changes in tree species assemblages. Oryx 38: 389-394.

Pijl, L. Van Der. 1972. Principles of dispersal in higher plants. Springer-Verlag, New York.

Pio Corrêa, M. 1926. Dicionário de Plantas Úteis e das Exóticas Cultivadas. Ministério da Agricultura, Indústria e Comércio. Imprensa Nacional, v. 1-6.

Pombal Jr., J.P. \& Izecksohn, E. 2011. Uma nova espécie de Brachycephallus (Anura, Brachycephallidae) do estado do Rio de Janeiro. Papéis Avulsos de Zoologia 51: 443-451.

Radford, A.E., Dickinson, W.C., Massey Jr., I.R. \& Bell, C.R. 1974. Vascular plants systematics. Harper \& Row, New York.

Radlkofer, L. 1931-1934. Sapindaceae. In: A. Engler. Das Pflanzenreich. Wilhelm Engelmann, Leipzig, IV-165. Heft 98-a-h-f. 1-46, pp. 1-1539.

Ribeiro, L.S. 1998. Município de Engenheiro Paulo de Frontin, um pouco de sua história e da sua gente. Sólon Ribeiro, Rio de Janeiro.
Silva, G.C. \& Nascimento, M.T. 2001. Fitossociologia de um remanescente de mata sobre tabuleiros no norte do estado do Rio de Janeiro (Mata de Carvão). Revista Brasileira de Botânica, 24: 51-62.

Somner, G.V. 1997. Sapindaceae. In: M.C. Marques, A.S.F. Vaz \& R. Marquete (orgs.). Flora da APA Cairuçu, Paraty, RJ. Espécies vasculares. Série Estudos e Contribuições, Rio de Janeiro. Instituto de Pesquisas Jardim Botânico do Rio de Janeiro, v. 14, pp. 456-492.

Somner, G.V. 2001. Sapindaceae. In: A.F. Costa \& I.C.A. Dias. Flora do Parque Nacional de Jurubatiba e arredores, Rio de Janeiro, Brasil: listagem, florística e fitogeografia, Museu Nacional, Rio de Janeiro, pp. 126-128.

Somner, G.V., Carvalho, A.L.G. \& Siqueira, C.T. 2009a. Sapindaceae da Restinga da Marambaia, Rio de Janeiro, Brasil. Rodriguésia 60: 485-507.

Somner, G.V., Ferrucci, M.S., M.M.T. Rosa, Coelho, R.L.G. 2009b. Sapindaceae. In: M.G.L. Wanderley, G.J. Shepherd, T.S. Melhem, A.M. Giulietti \& S.E. Martins. Flora Fanerogâmica de São Paulo. Instituto de Botânica, FAPESP, v. 6, pp. 1-70.

Somner, G.V., Frazão, A. \& Ferrucci, M.S. 2013. Allophylus exappendiculatus (Sapindaceae), a new species from Rio de Janeiro, Brazil. Annales Botanici Fennici 50: 401-404.

Somner, G.V., Ferrucci, M.S., Acevedo-Rodríguez, P., Coelho, R.L.G. \& Perdiz, R. 2015. Sapindaceae. Lista de Espécies da Flora do Brasil. Jardim Botânico do Rio de Janeiro. Disponível em http://floradobrasil.jbrj.gov. br/jabot/floradobrasil/FB216 (acesso em 31-V-2015).

Tabarelli, M., Silva, J.M.C. \& Gascon, C. 2004. Forest fragmentation, synergisms and the impoverishment of neotropical forest. Biodiversity and Conservation 13: 1419-1425.

Tropicos. 2016. Missouri Botanical Garden. Disponível em http://www.tropicos.org/ (acesso em 09-VII-2016).

Veloso, H.P., Rangel Filho, A.L.R. \& Lima, J.C.A. 1991. Classificação da vegetação brasileira, adaptada a um sistema universal. IBGE, Departamento de Recursos Naturais e Estudos Ambientais, Rio de Janeiro. 